\title{
SOME DATA ABOUT A POSSIBLE FRAGMENT OF A ROMAN HOARD IN THE "ALEXANDRU BORZA" NUMISMATIC COLLECTION
}

\begin{abstract}
In May, 1971, the museum in Alba Iulia acquired the numismatic collection of Professor Alexandru Borza. Analyzing the Roman Imperial coins from this collection, we noticed certain characteristics of some of the parts that caught our attention such as their gilding and the fact that they were used in a necklace, as on each piece, one, two or three lugs were glued. These things have shown us that the coins came from a greater hoard. This monetary fragment consisting of 23 silver parts (17 denarii and 6 antoniniani) of which 3 denarii emitted by Septimius Severus, one coin emitted by Septimius Severus: Caracalla (Caesar), 1 coin by Septimius Severus: Caracalla (Augustus), 3 denarii emitted by Elagabalus, one coin by Elagabalus - Iulia Soaemias, 6 denarii by Severus Alexander, 2 denarii by Severus Alexander: Iulia Mamaea, 4 antoniniani by Gordian III and two antoniniani by Philip I. Thus, we can say that this money fragment falls into the second group of completed hoard of coin from Philip and hidden, perhaps during the reign of Trajan Decius.

Keywords: coins, Alexandru Borza, monetary fragment, hoard, denarii, antoniniani, Philip I, numismatic collection, Gothic invasion.
\end{abstract}

\section{Ovidiu-Maxim Oargă}

National Museum of Union Alba Iulia ovidiu_maxim_oarga@yahoo.com

DOI: $10.14795 /$ j.v6i1.392

ISSN 2360 - 266X

ISSN-L 2360 - 266X
$\mathbf{I}$

n May 1971, the museum in Alba Iulia acquired the numismatic collection of Professor Alexandru Borza. It consists of 1661 numismatic pieces of which 47 are Greek coins, 6 Dacian coins, 112 Roman Republican coins, 740 Roman Imperial coins, 122 Byzantine coins, 124 medieval coins, 496 modern coins and 4 medals.

Unfortunately, for the most of these coins the place where they had been discovered or the way they had been discovered is unknown. The little information about this aspect is provided in articles such as Judith Winkler's article, The Monetary Circulation in Apulum ${ }^{1}$, where we can learn that some of the numismatic material found in the city entered the collection of Professor Al. Borza or Michael Blăjan The Monetary circulation in Alba county, an argument for the Roman continuity in post-Roman Dacia (270 A.D. - the $7^{\text {th }}$ century AD) ${ }^{2}$ which states that in the last decade, many of the coins discovered in Alba county went to various museums (Cluj-Napoca, Târnăveni, Constanța) or in private collections (Feher, Al. Borza).

Finally, Borza, in his Memoirs of a Botanist in Alba Iulia - autobiographical $n^{n}$ tes $^{3}$, relates that during his adolescence, he also enriched, among other collections, the numismatic collection which comprised nearly 60 Roman coins and hundreds of modern Austrian and foreign coins. In particular, he loved the Roman coins gathered occasionally in Alba Iulia, to their purchase being helped by two of the boys in his father's warehouse, Avram Oargă and Nicolae Stanciu, who were considered as family members.

WINKLER, 1965, 217

BLĂJAN, 1985, 95.

3 BORZA, 1963, 2.

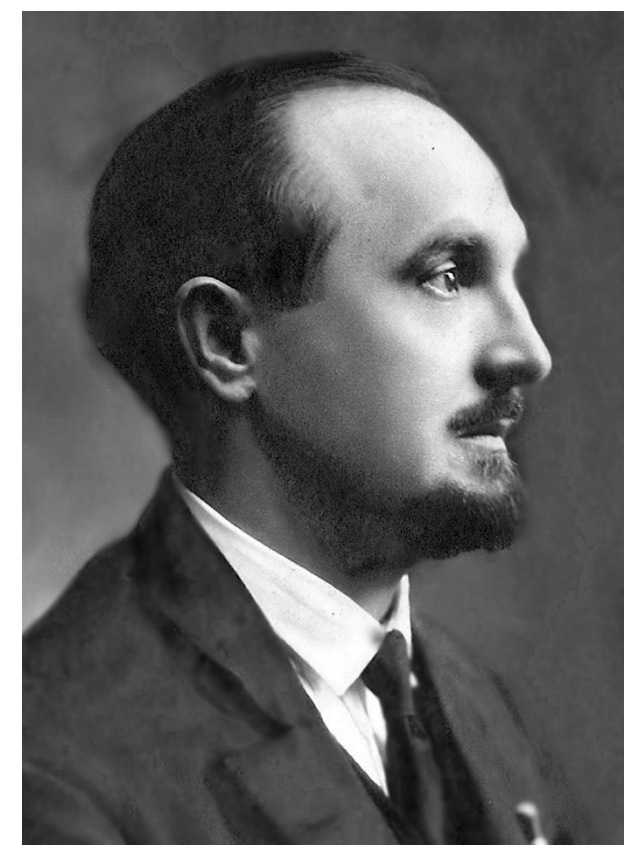

Alexandru Borza (1887-1971)

Sursa foto: https://editiadedimineata.ro/ pe-urmele-unui-iubitor-al-naturii-alexandru-borza-de-la-gradina-botanica-din-cluj-napoca-la-primul-parc-national-din-romania/ 
We only know the source of a few coins in this collection, respectevely by purchasing from the different antique dealers in the country or abroad (Bucharest, Oradea, Milan, Alba Iulia).

Analyzing the Roman Imperial coins from this collection, we noticed certain characteristics of some of the parts that caught our attention such as their gilding and the fact that they were used in a necklace, as on each piece, one, two or three lugs were glued. These things have shown us that the coins came from a greater hoard (see catalogue and plates 1-3).

This monetary fragment consisting of 23 silver parts, 17 denarii and 6 antoniniani, (see graph 1 ) of which 3 denarii emitted by Septimius Severus, one coin emitted by Septimius Severus: Caracalla (Caesar), 1 coin by Septimius Severus: Caracalla (Augustus), 3 denarii emitted by Elagabalus, one coin by Elagabalus for Julia Soaemias, 6 denarii by Severus Alexander, 2 denarii by Severus Alexander: Iulia Mamaea, 4 antoniniani by Gordian III and two antoniniani by Philip I (see graph 2).

\section{CATALOGUE}

\section{SEPTIMVS SEVERVS}
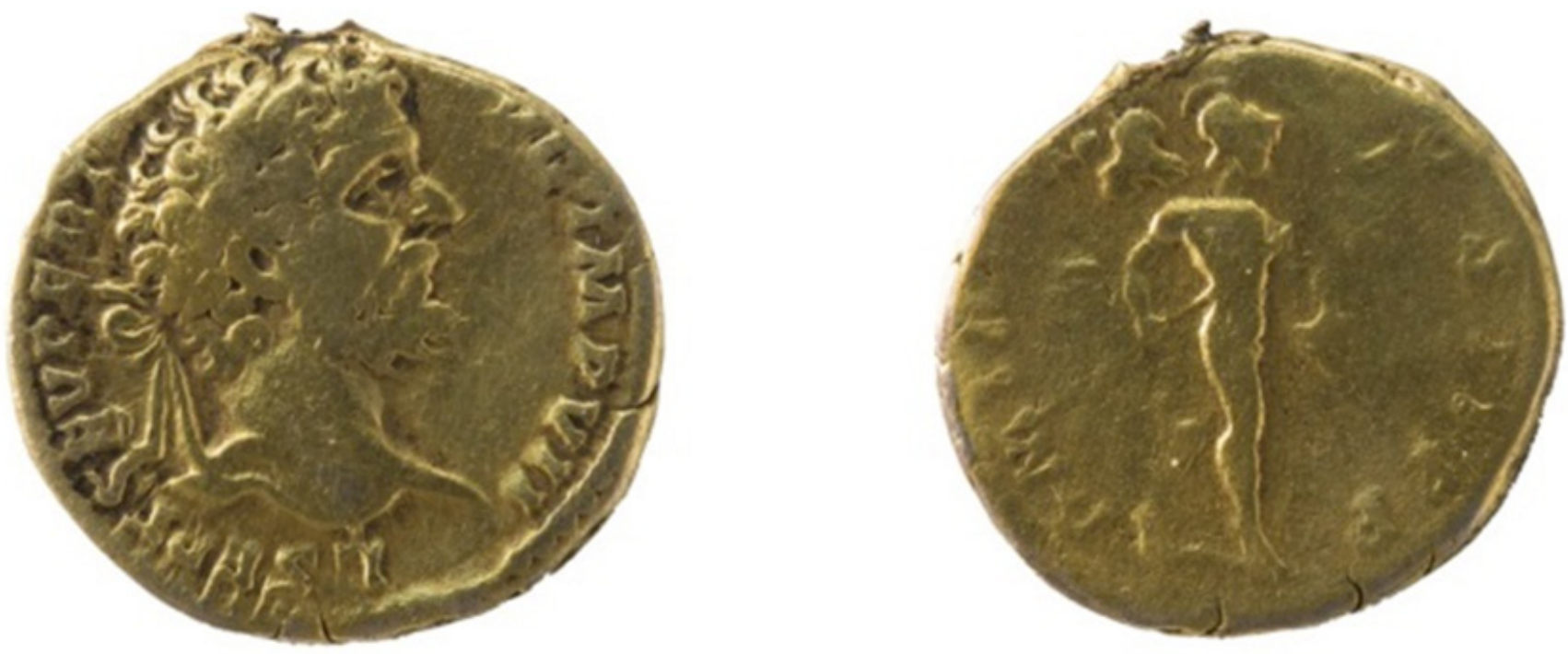

1.

Nominal: denarius;

Axis: 12. D: $18,1 \mathrm{~mm} . \quad$ W: 2,99 g.

Mint: $\quad$ Rome;

Dating: 195-196;

Obverse: L SEPT SEV PERT [a]VG IMP VII

Head of Septimius Severus, laureate, to the right;

Reverse: $\quad$ P M TR [p] [i]]I COS II PP

Mars, nude, with a helmet, with a jacket attached to the waist, advancing to the right, holding spear in right hand and trophy in left hand;

Catalogue: RIC IV/1, no. 67;

Inv. no. 5378; 

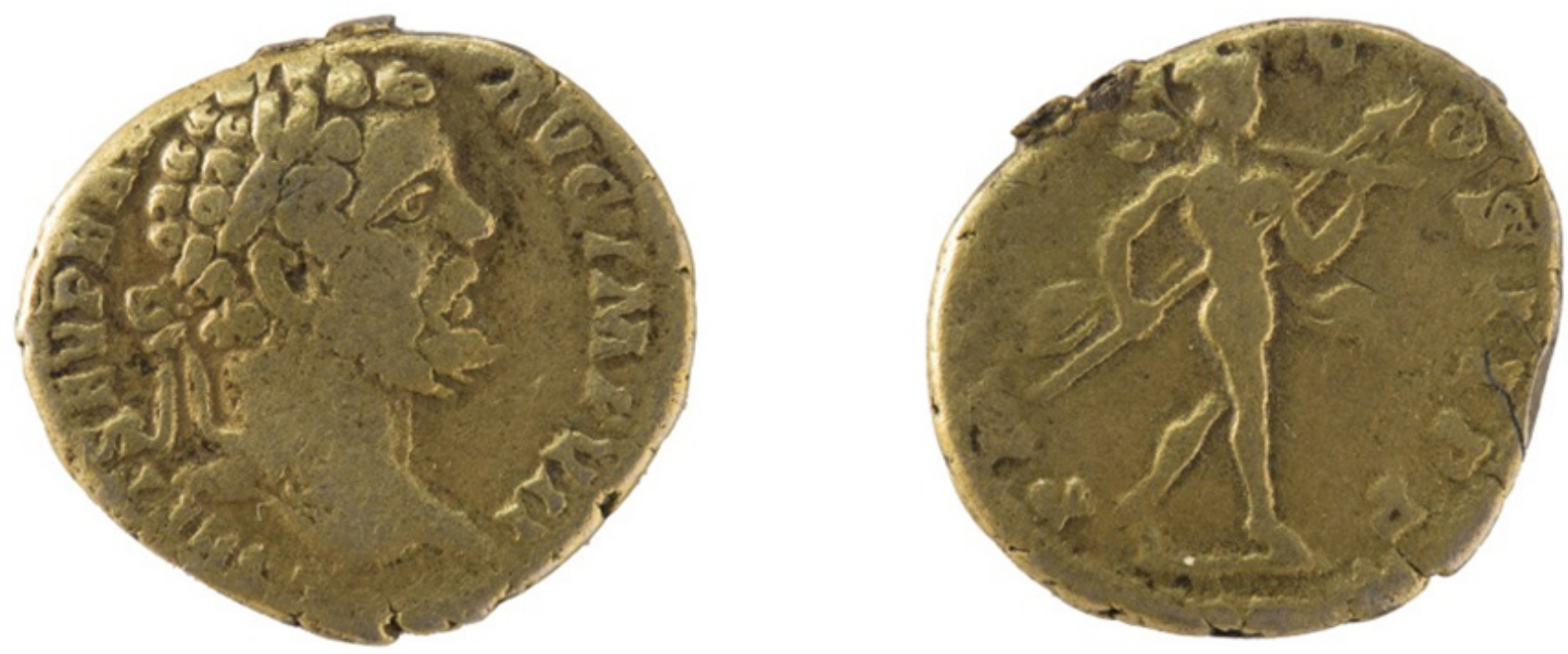

2.

Nominal: denarius;

Axis: $1 . \quad$ D:18.1 mm. W: $3.08 \mathrm{~g}$.

Mint: $\quad$ Rome;

Dating: 195-196;

Obverse: [1 s]EPT SEV PER[t] AVG IMP VII

Head of Septimius Severus, laureate, to the right;

Reverse: $\quad$ P M [trp] [iii] COS II PP

Mars, nude, with a helmet, with a jacket attached to the waist, advancing to the right, holding spear in right hand and trophy in left hand;

Catalogue: RIC IV/1, no. 67;

Inv. no. 5380;
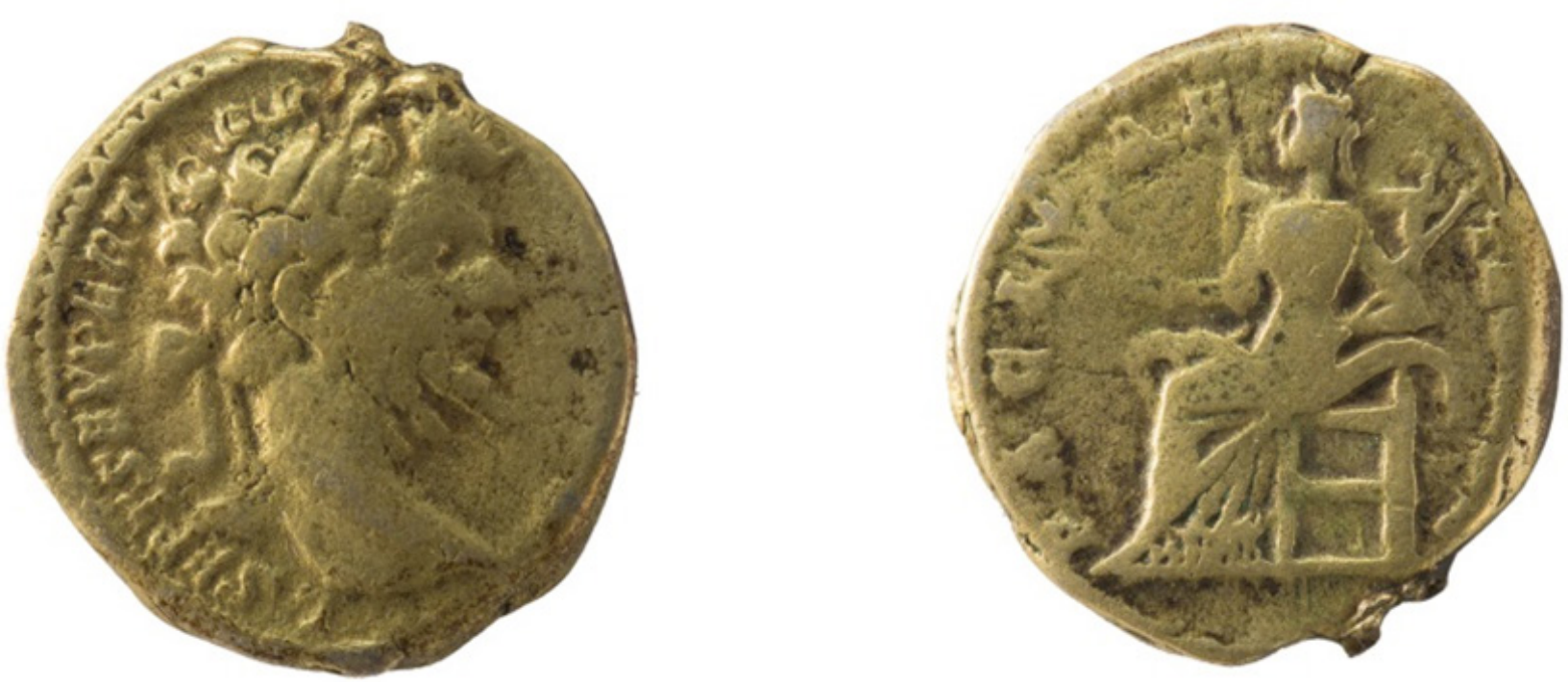

3.

Nominal: denarius;

Axis: 6. D: $17.1 \mathrm{~mm} . \quad$ W: $3.34 \mathrm{~g}$.

Mint: Rome;

Dating: 197-198;

Obverse: L SEPT SEV PERT [avg imp x]

Head of Septimius Severus, laureate, to the right;

Reverse: PACI AE-T[ernae]

Pax draped, seated to the left, holding branch in right hand and sceptre in left hand;

Catalogue: RIC IV/1, no. 118;

Inv. no. 5379; 

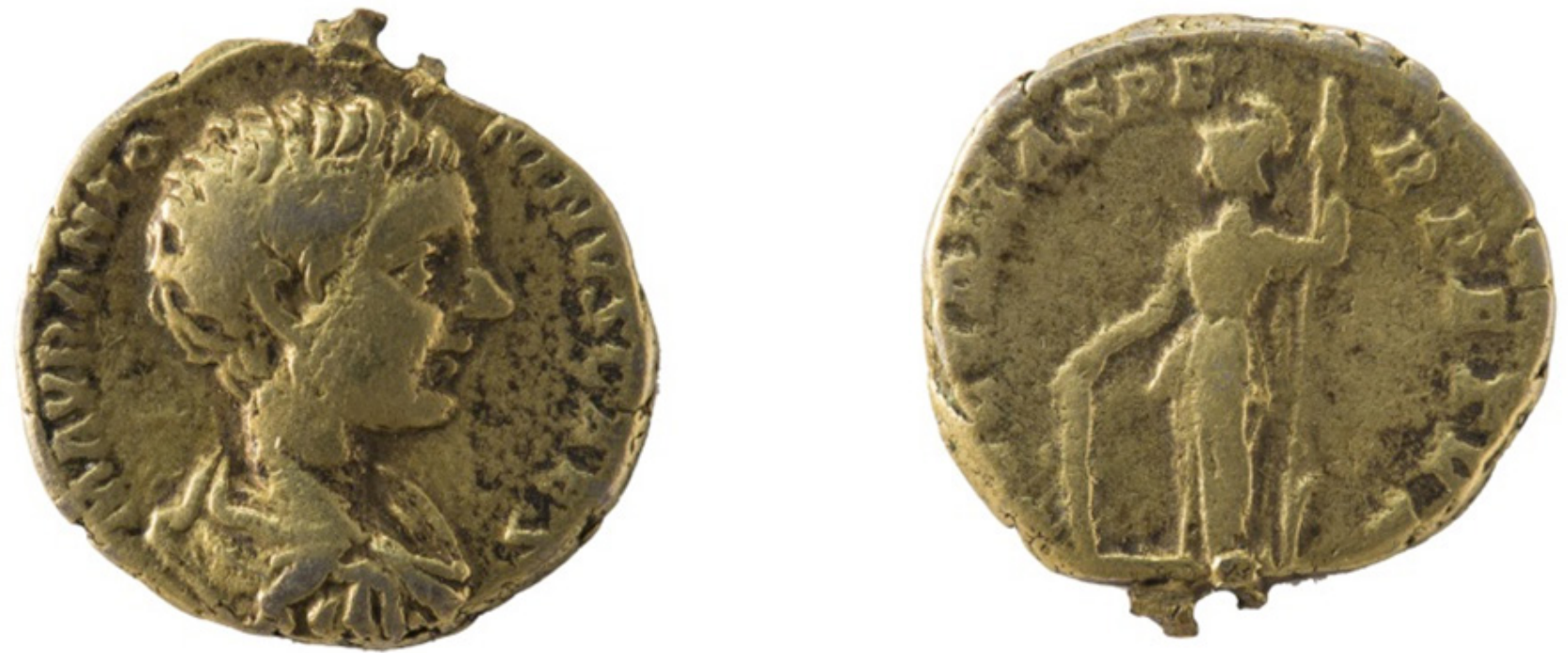

4.

Nominal: denarius;

Axis: 6. D: $17.6 \mathrm{~mm} . \quad W: 3.33 \mathrm{~g}$.

Mint: $\quad$ Rome;

Dating: 196;

Obverse: M AVR ANTO-NINVS CAES

Bust of Caracalla, draped, cuirassed, to the right;

Reverse: [secvri]TAS PE-RPETVA

Minerva, with aegis on breast, standing to the left, resting right hand on shield and holding spear in left hand;

Catalogue: RIC IV/1, no. 2;

Inv. no. 5394;

\section{SEPTIMIVS SEVERVS: Caracalla (Augustus)}
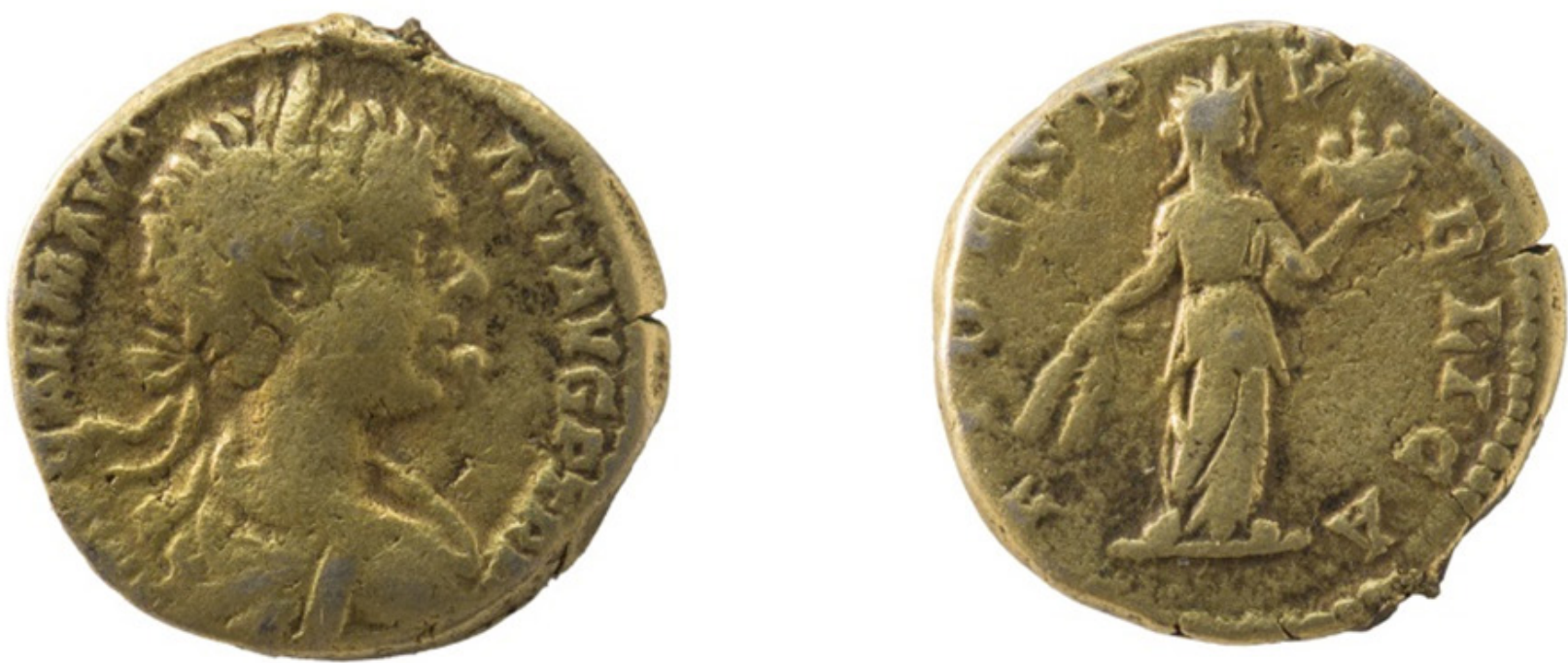

5.

Nominal: denarius;

$\begin{array}{lll}\text { Axis: } 6 . & \text { D: } 17 \mathrm{~mm} . & W: 3,27 \mathrm{~g} . \\ \text { Mint: } & \text { Rome; }\end{array}$

Mint: Rome;

Dating: 198 ;

Obverse: [imp] CAE M AVR ANT AVG P TR P

Bust of Caracalla, draped, cuirassed, to the right;

Reverse: FIDES P-V-BLICA

Fides, draped, standing to the right, holding corn-ears in right hand and basket of fruit in left hand;

Catalogue: RIC IV/1, no. 24a; 


\section{ELAGABALVS}
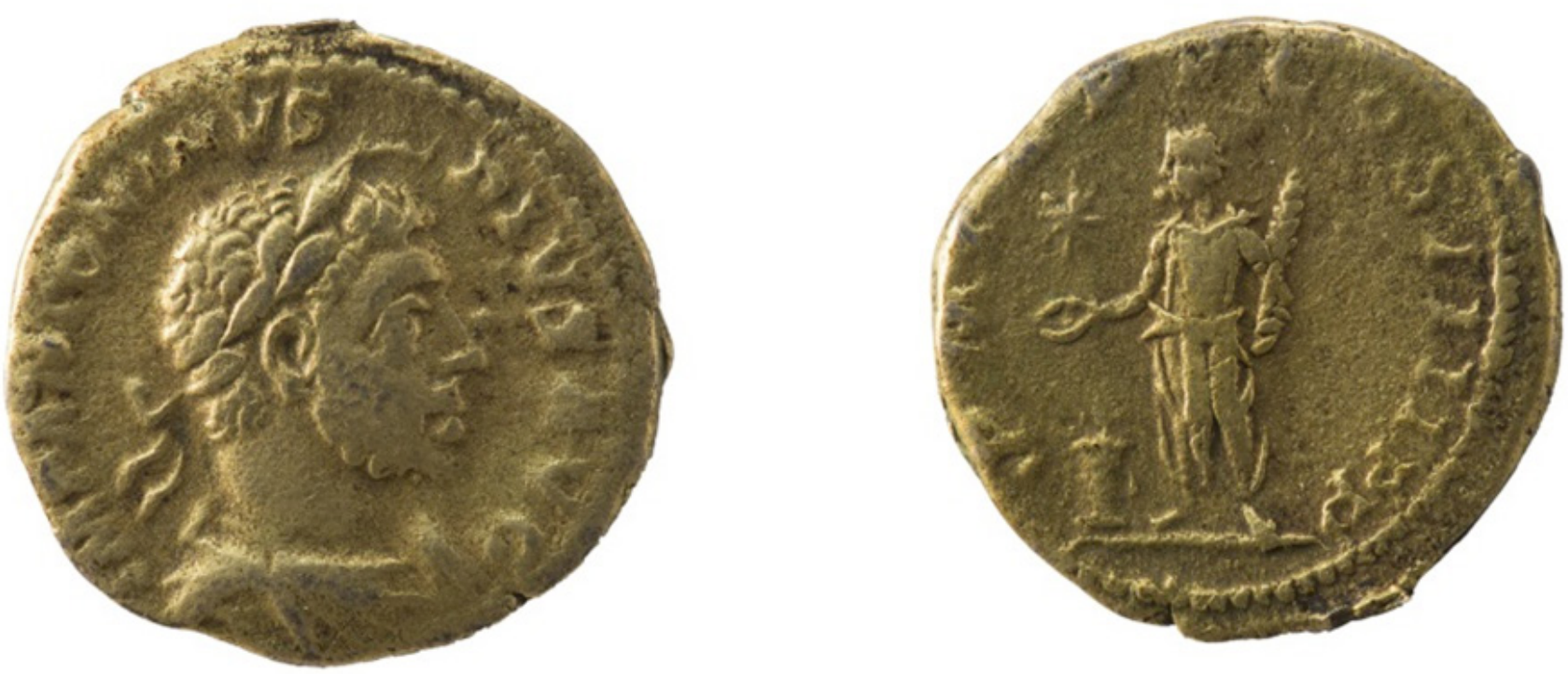

6.

Nominal: denarius;

Axis: 6. D: $18.8 \mathrm{~mm} . \quad W: 2.83 \mathrm{~g}$.

Mint: Rome;

Dating: 222;

Obverse: IMP ANTONINVS PIVS AVG

Bust of Elagabalus, laureate, draped, to the right;

Reverse: $\quad$ P M TR P V COS IIII P P

Elagabalus, standing to the right, sacrificing left over lighted altar, holding patera in right hand and club in left hand; in field, star;

Catalogue: RIC IV/2, no. 52;

Inv. no. 5428;
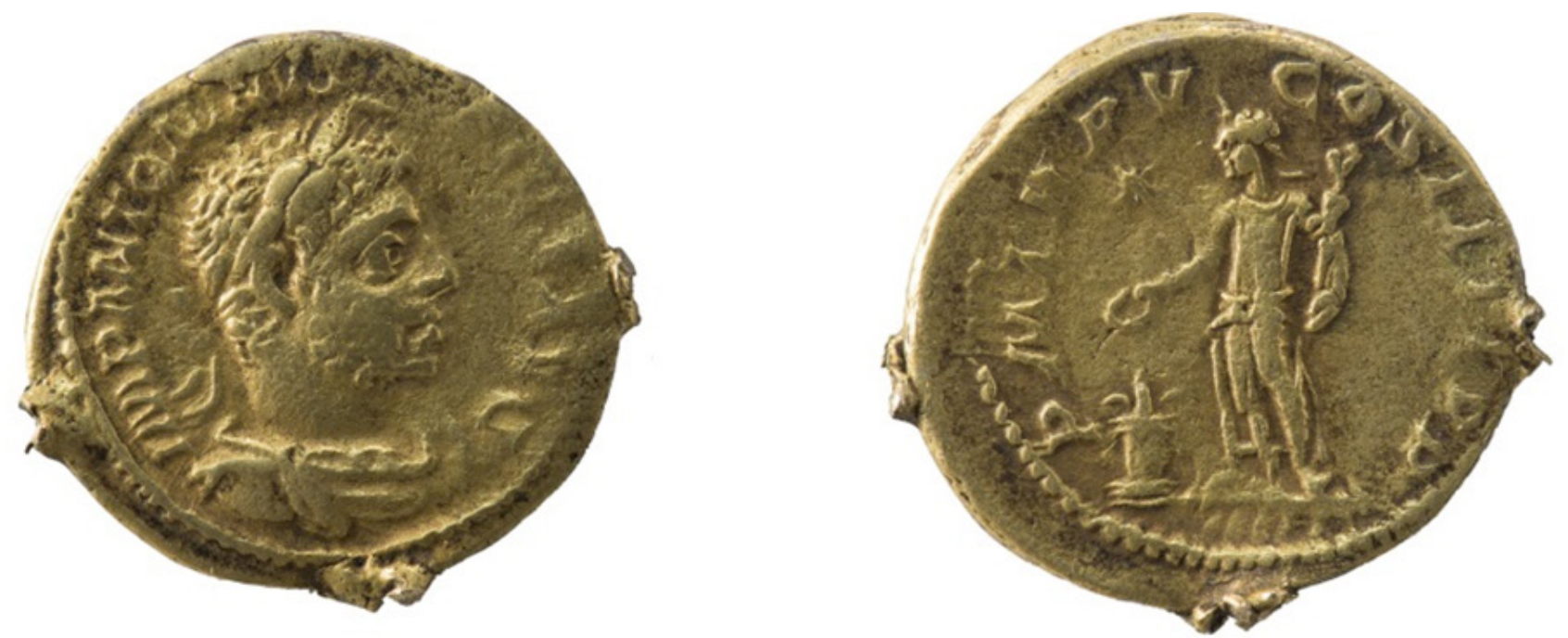

7.

Nominal: denarius;

Axis: 12. D: $20.8 \mathrm{~mm}$. W: $2.92 \mathrm{~g}$.

Mint: Rome;

Dating: 222;

Obverse: IMP ANTONINVS [pivs] AVG

Bust of Elagabalus, laureate, draped, to the right;

Reverse: $\quad$ P M TR P V COS IIII P P 
Elagabalus, standing to the right, sacrificing left over lighted altar, holding patera in right hand and club in left hand; in field, star;

Catalogue: RIC IV/2, no. 52;

Inv. no. 5429;
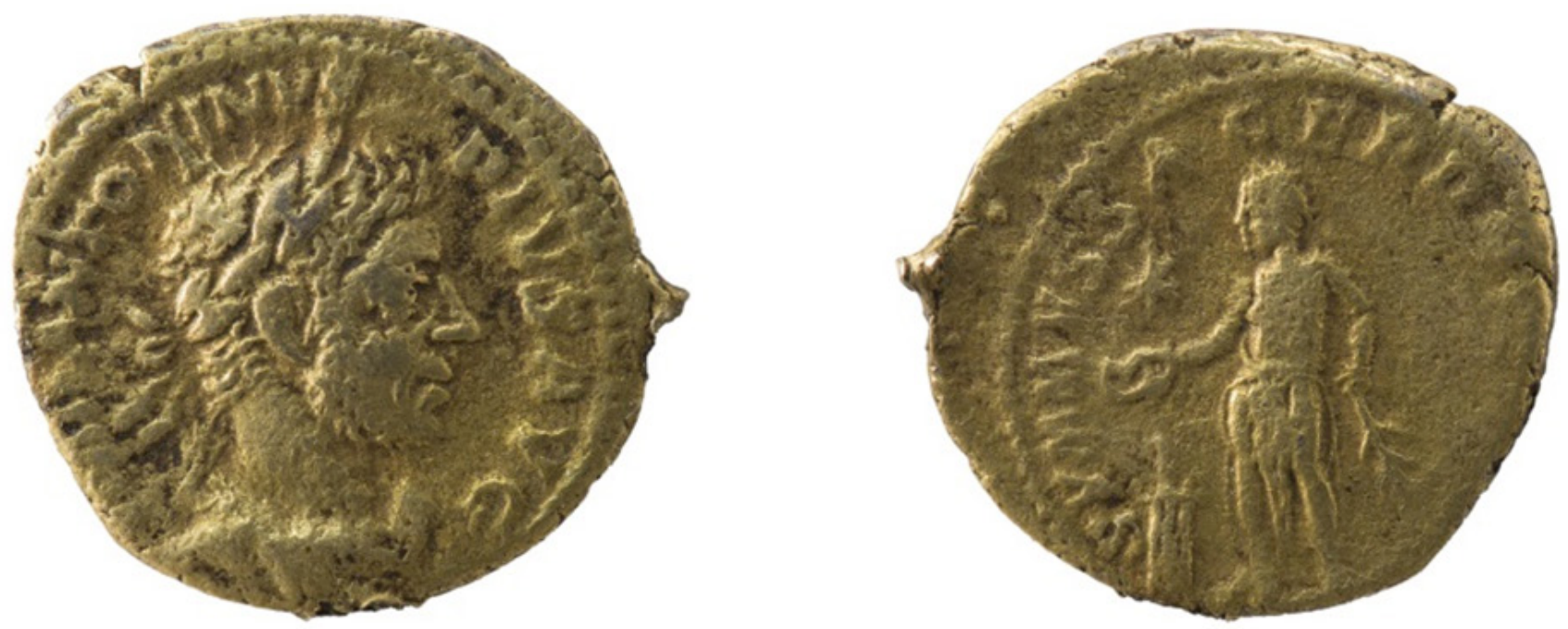

8.

Nominal: denarius;

Axis: $12 . \quad$ D: $18.8 \mathrm{~mm} . \quad W: 3.09 \mathrm{~g}$.

Mint: $\quad$ Rome;

Dating: 218-222;

Obverse: [i]MP ANTONINVS PIVS AVG

Bust of Elagabalus, laureate, draped, to the right;;

Reverse: SVMMVS SACERDO[s avg]

Elagabalus, standing to the left, sacrificing over tripod, holding patera in right hand and branch in left hand; in field, star;

Catalogue: RIC IV/2, no. 146;

Inv. no. 5427;

ELAGABALVS: Julia Soaemias
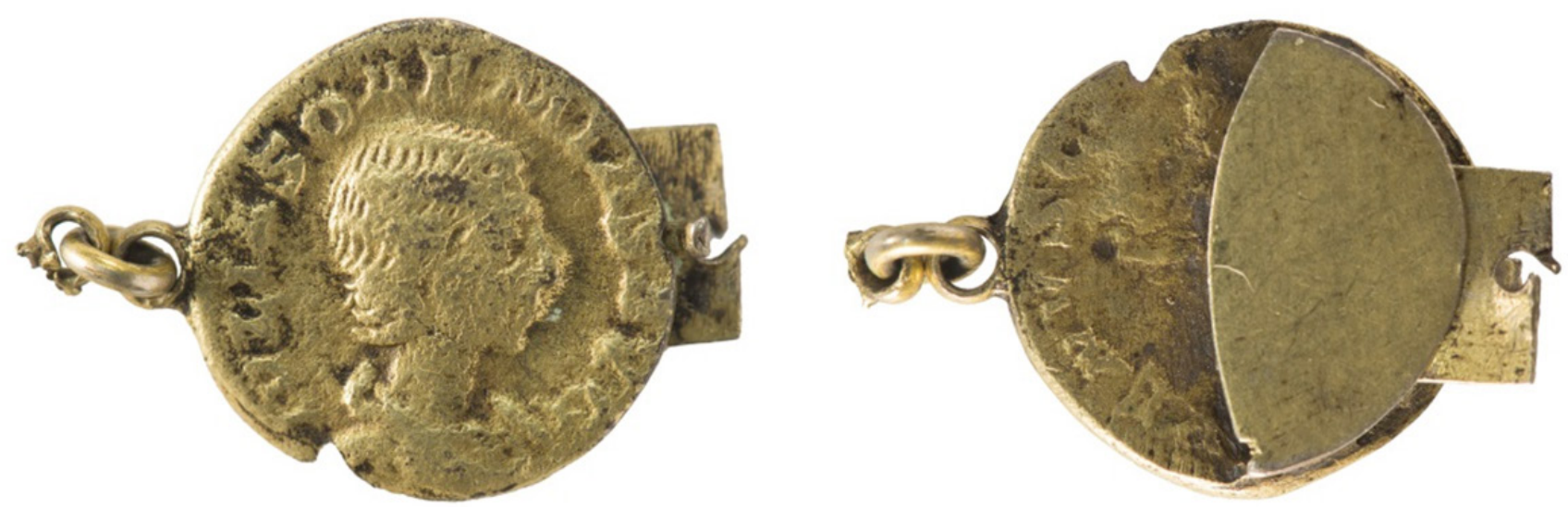

9.

Nominal: denarius;

Axis: 6. D: $17 \mathrm{~mm} . \quad W: 3.88 \mathrm{~g}$.

Mint: Rome;

Dating: 218-222;

Obverse: IVLIA SOAEMIAS AVG

Bust of Julia Soaemias, draped, to the right, hair drawn back;

Reverse: VENVS C[a-elestis]

Venus, diademed, standing to the left, holding apple in right hand (and sceptre in left hand; in field, star);

Catalogue: RIC IV/2, no. 241; 


\section{SEVERUS ALEXANDER}
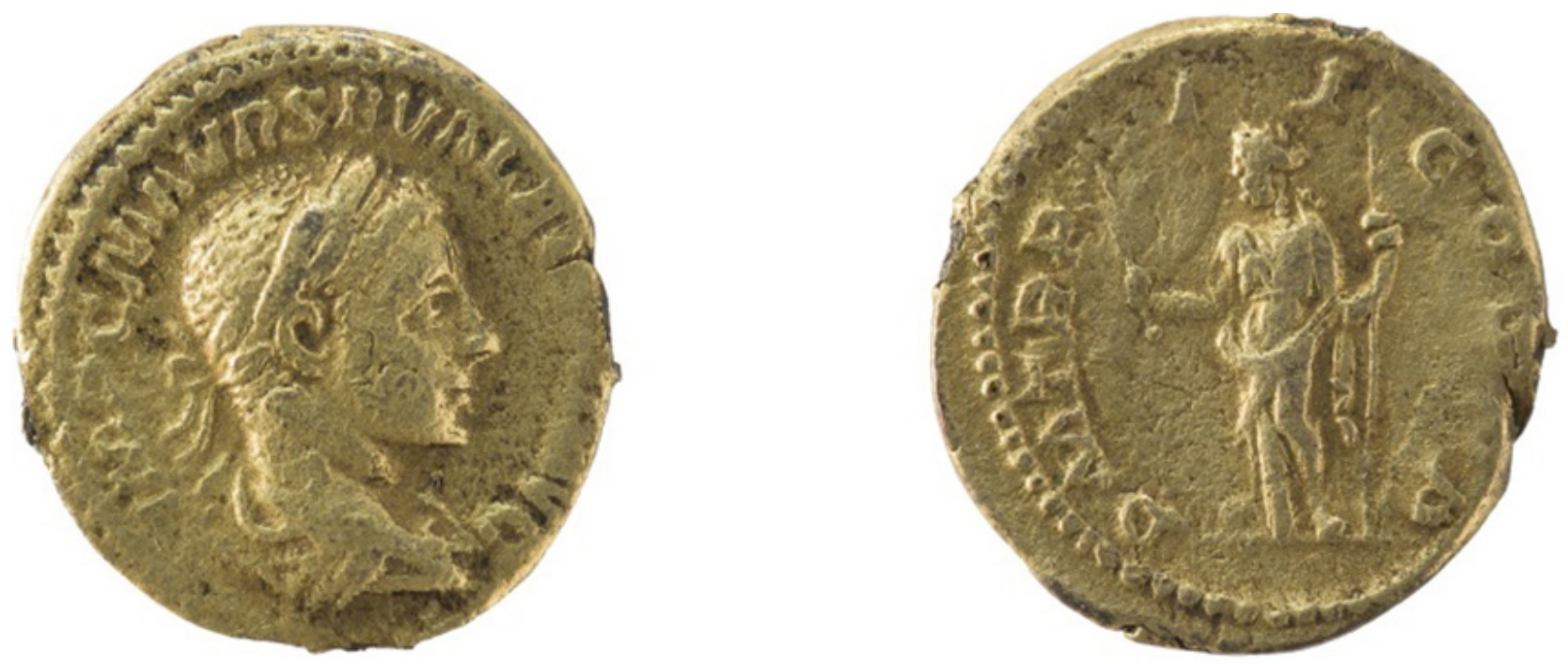

10.

Nominal: denarius;

Axis: 6. D: $19 \mathrm{~mm} . \quad W: 3,38 \mathrm{~g}$.

Mint: Rome;

Dating: 223;

Obverse: IMP C M AVR SEV ALE[xand a]VG

Bust of Severus Alexander, laureate, draped, to the right;

Reverse: $\quad$ P M TR P-I-I-COS PP

Pax draped, standing to the left, holding olive-branch in right hand and sceptre in left hand;

Catalogue: RIC IV/2, no. 27;

Inv. no. 5456;
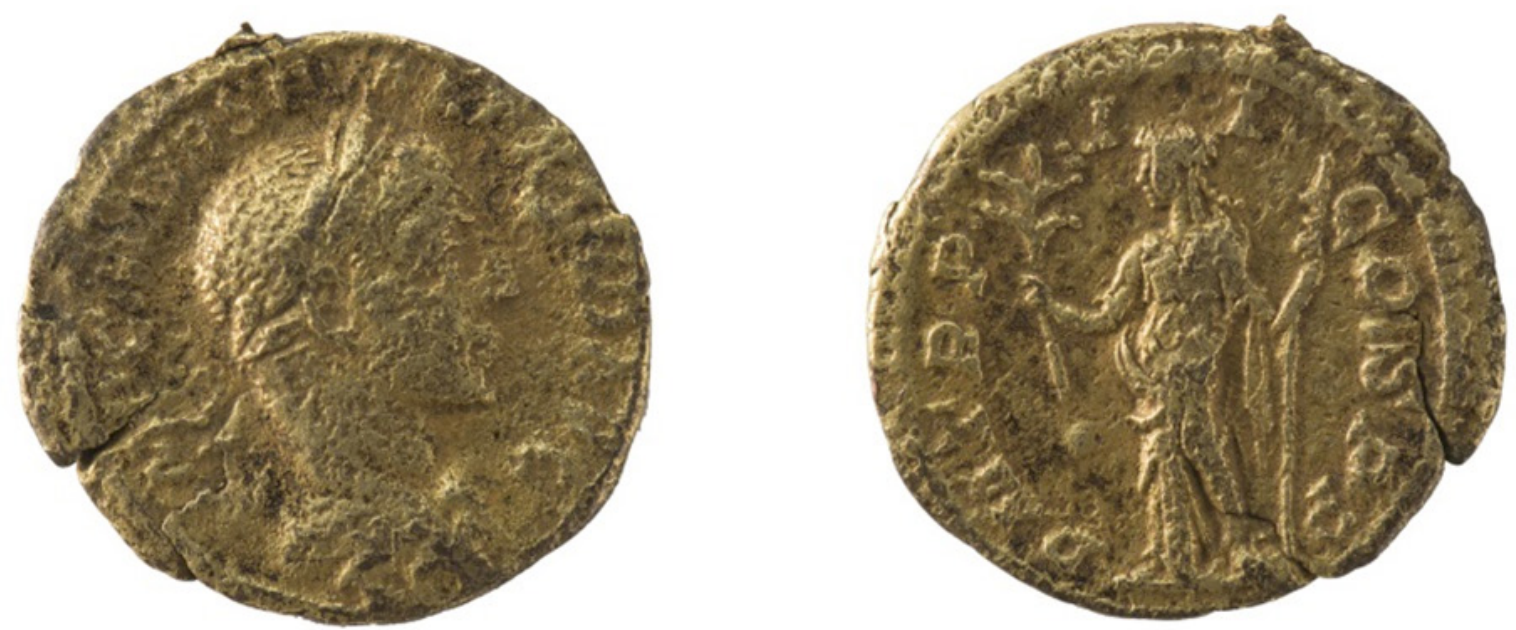

11.

Nominal: denarius;

Axis: 12. D: $19.4 \mathrm{~mm} . \quad W: 2.29 \mathrm{~g}$.

Mint: $\quad$ Rome;

Dating: 223;

Obverse: IMP C M AVR SEV ALEX[and avg]

Bust of Severus Alexander, laureate, draped, to the right;

Reverse: $\quad$ P M TR P-I-I-COS PP

Pax draped, standing to the left, holding olive-branch in right hand and sceptre in left hand;

Catalogue: RIC IV/2, no. 27;

Inv. no. 5457; 

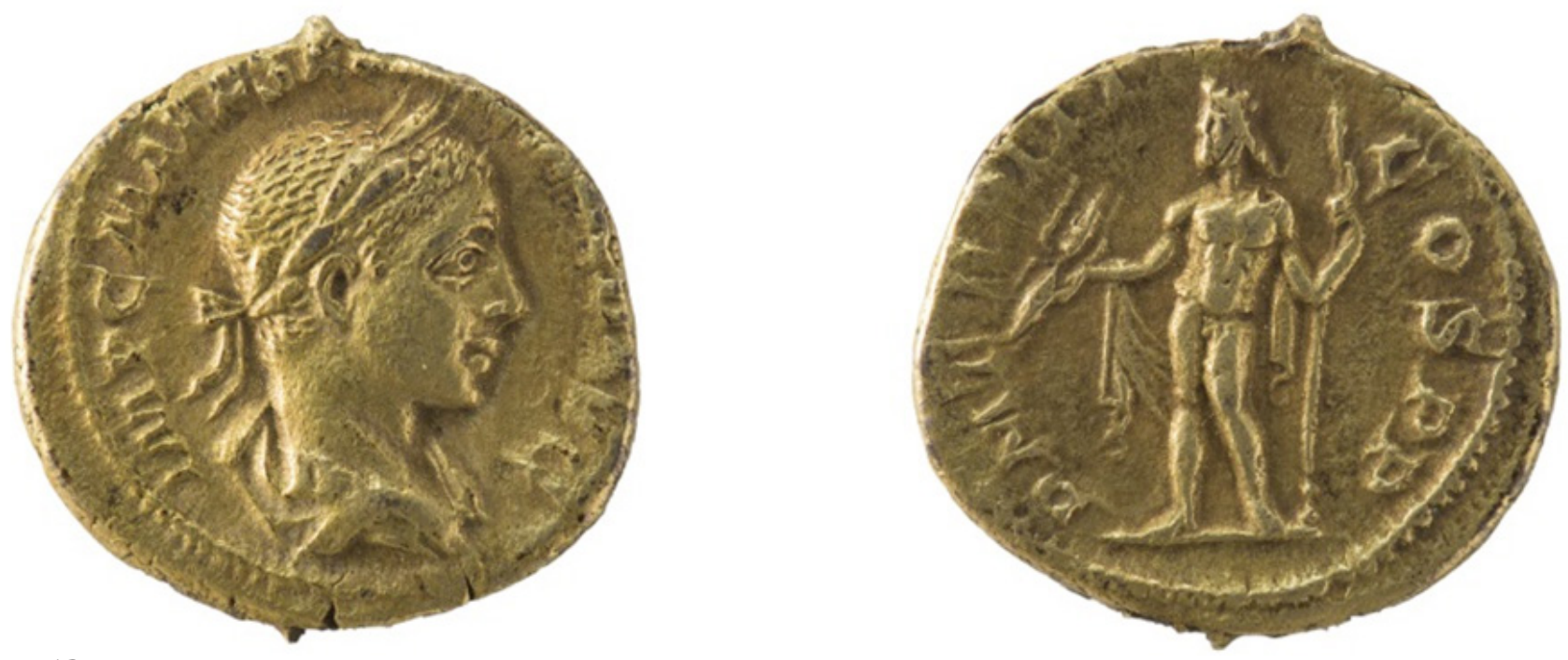

Nominal: denarius;

Axis: $12 . \quad$ D: $18.5 \mathrm{~mm} . \quad W: 3.55 \mathrm{~g}$.

Mint: Rome;

Dating: 224;

Obverse: IMP C M AVR SE[v] [alexand] AVG

Bust of Severus Alexander, laureate, draped, to the right;

Reverse: $\quad$ P M TR P III-COS PP

Jupiter standing to the left, cloak behind and over right arm, holding thunderbolt in right hand and sceptre in left hand;

Catalogue: RIC IV/2, no. 35;

Inv. no. 5459;
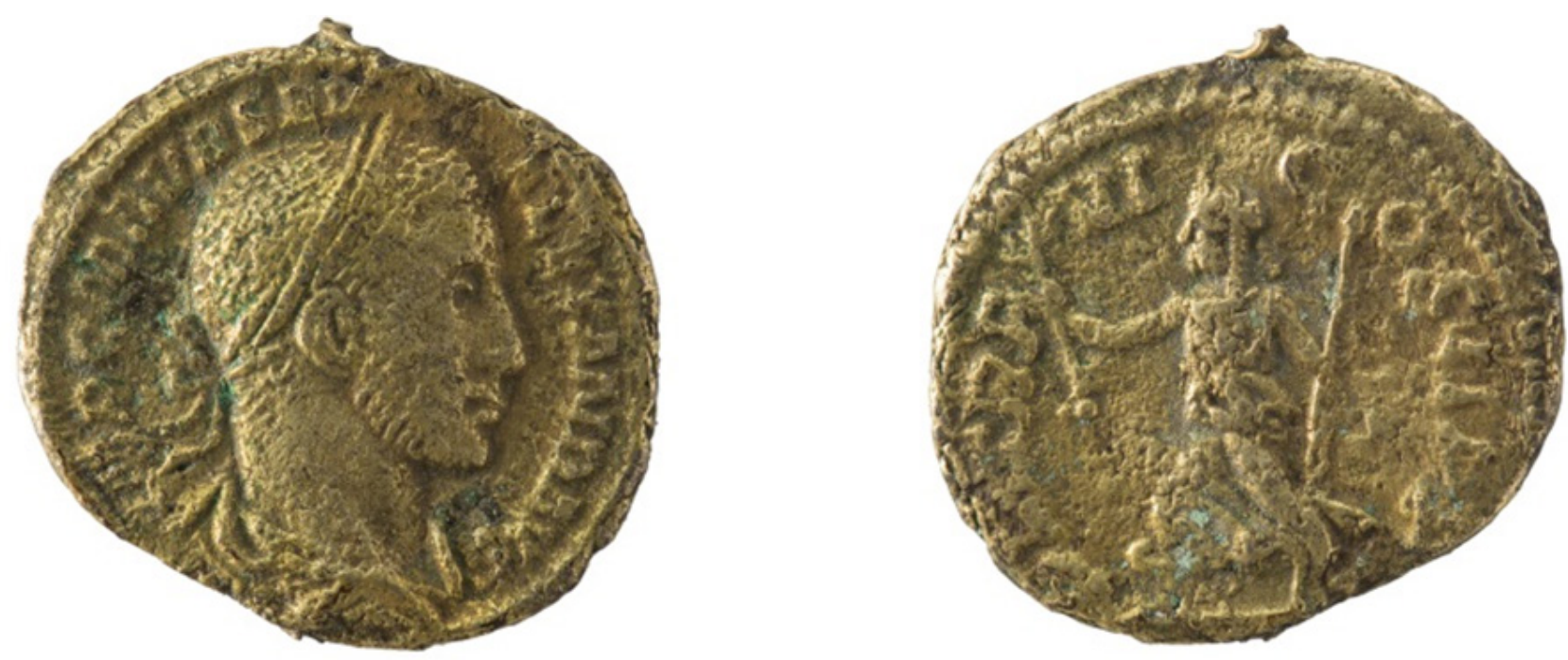

13.

Nominal: denarius;

Axis: $12 . \quad$ D: $18.7 \mathrm{~mm} . \quad$ W: $2.93 \mathrm{~g}$.

Mint: Rome;

Dating: 227;

Obverse: IMP C M AVR SEV ALEXAND AVG

Bust of Severus Alexander, laureate, draped, to the right;

Reverse: $\quad$ P M TR P VI COS II PP

Pax, draped, running to the right, holding olive-branch in right hand and sceptre in left hand;

Catalogue: RIC IV/2, no. 67;

Inv. no. 5458; 

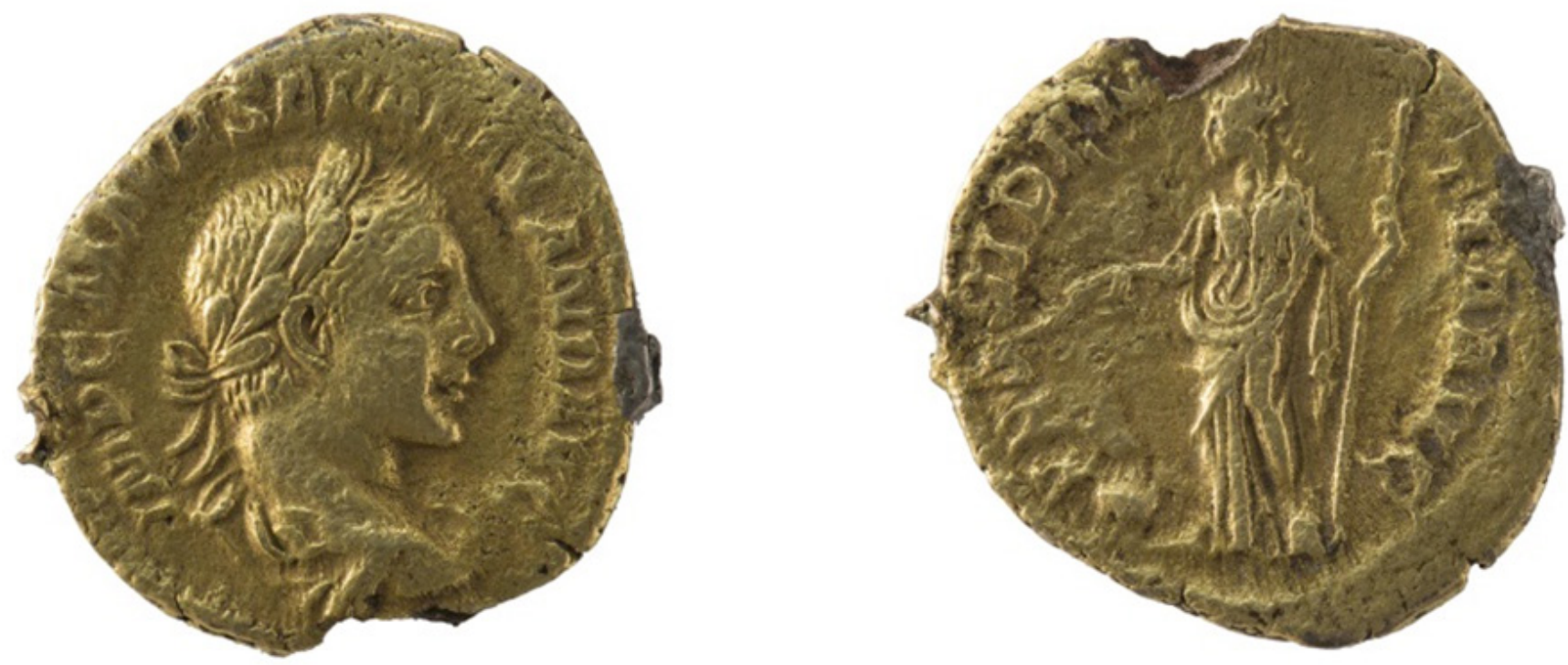

14.

Nominal: denarius;

Axis: 6. D: $19.2 \mathrm{~mm}$. W: $2.72 \mathrm{~g}$.

Mint: Rome;

Dating: 222-228;

Obverse: IMP C M AVR SEV ALEXAND AVG

Bust of Severus Alexander, laureate, draped, to the right;

Reverse: PROVIDEN-TIA AVG

Providentia, draped, standing to the right, holding wand in right hand and sceptre in left hand; at her feet, a globe;

Catalogue: RIC IV/2, no. 173;

Inv. no. 5454;
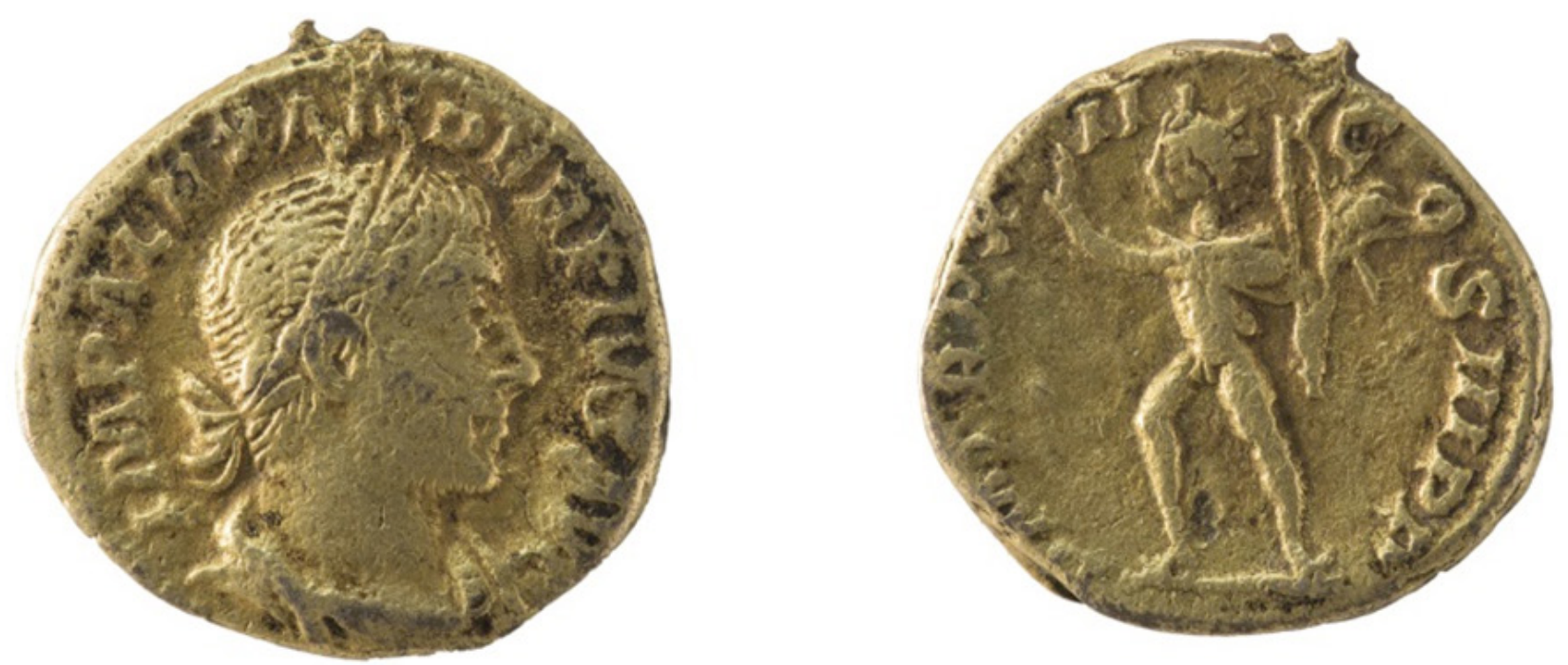

15.

Nominal: denarius;

Axis: $12 . \quad$ D: $18.3 \mathrm{~mm} . \quad W: 3.36 \mathrm{~g}$.

Mint: $\quad$ Rome;

Dating: 233;

Obverse: IMP ALEXANDER PIVS AVG

Bust of Severus Alexander, laureate, draped, to the right;

Reverse: $\quad$ P M TR P X-II- C-OS III PP

Sol radiate, walking to the left, holding whip in left hand;

Catalogue: RIC IV/2, no. 120;

Inv. no. 5455; 
SEVERUS ALEXANDER: Julia Mamaea
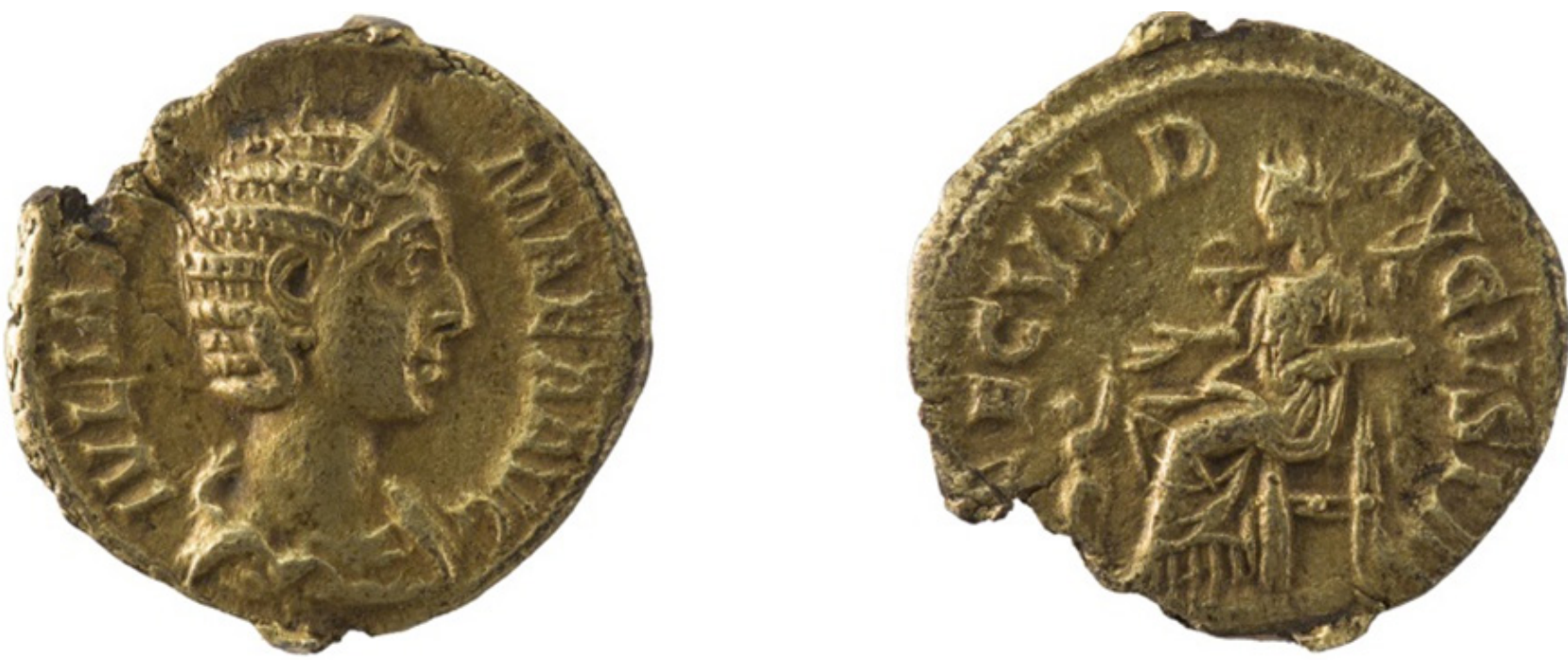

16.

Nominal: denarius;

Axis: 6. D: $18.8 \mathrm{~mm} . \quad W: 2.08 \mathrm{~g}$.

Mint: $\quad$ Rome;

Dating: 225-235;

Obverse: IVLIA MA-MAEA AVG

Bust of Julia Mamaea, diademed, draped, to the right;

Reverse: FECVND AVGVSTAE

Fecunditas, draped, seated to the left, holding hand of child and resting her left arm on seat;

Catalogue: RIC IV/2, no. 332;

Inv. no. 5482;
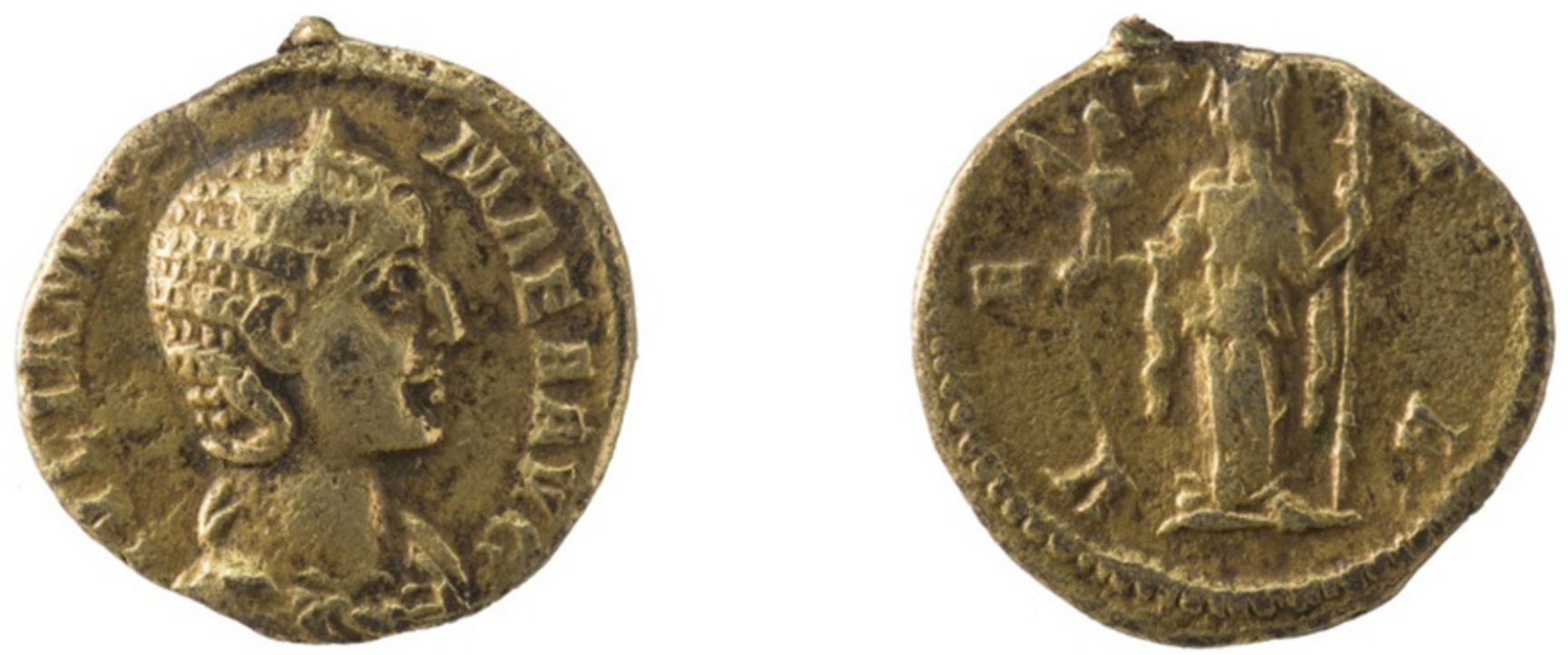

17.

Nominal: denarius;

Axis: $1 . \quad$ D: $18.1 \mathrm{~mm} . \quad W: 2.82 \mathrm{~g}$.

Mint: $\quad$ Rome;

Dating: 225-235;

Obverse: [iv]LIA MA-MAEA AVG

Bust of Julia Mamaea, diademed, draped, to the right;

Reverse: VE-S-TA

Vesta veiled, draped, standing to the left, holding palladium in right hand and sceptre in left hand;

Catalogue: RIC IV/2, no. 360;

Inv. no. 5481; 


\section{GORDIANVS III}
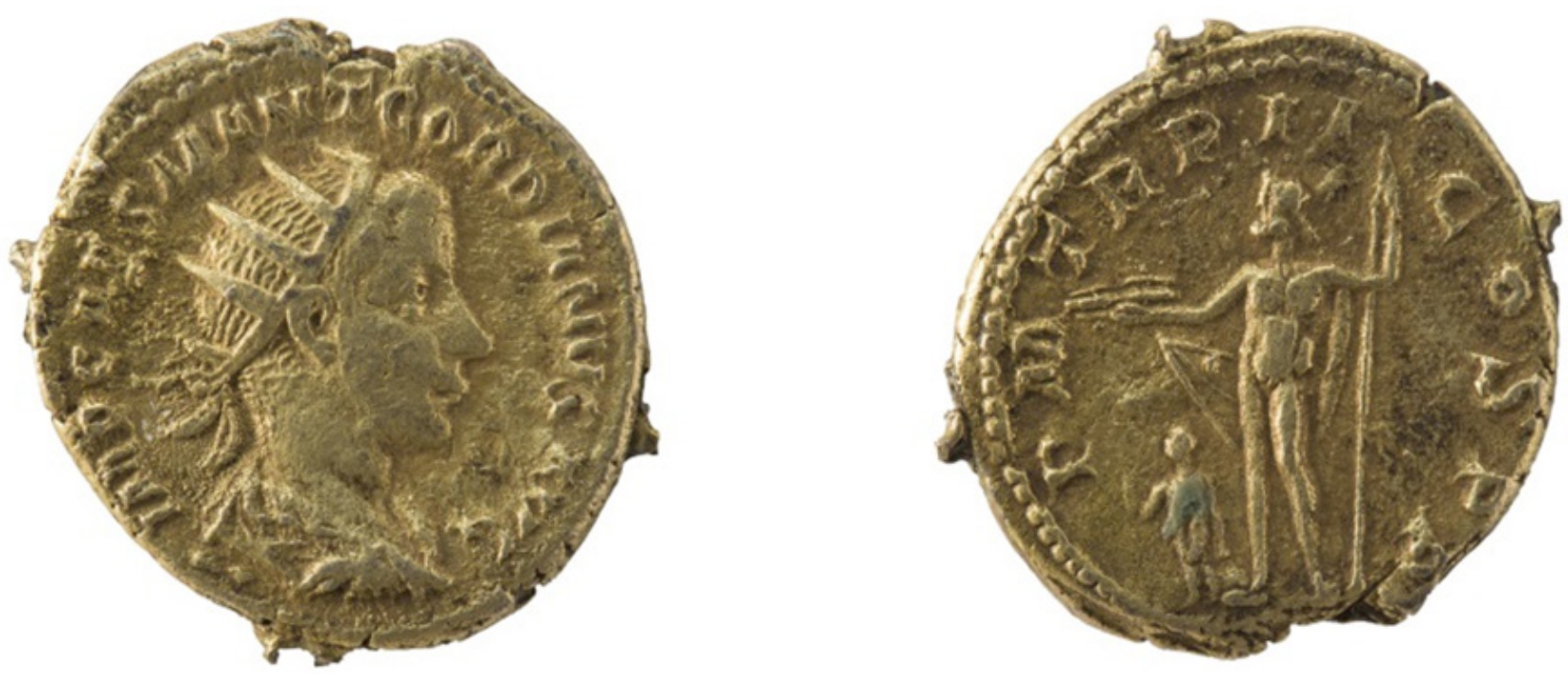

18.

Nominal: antoninianus;

Axis: 6. D: $21.6 \mathrm{~mm} . \quad$ W: $5.36 \mathrm{~g}$.

Mint: $\quad$ Rome;

Dating: 239;

Obverse: IMP CAES M ANT GORDIANVS AVG

Bust of Gordianus III, radiate, draped, cuirassed, to the right;

\section{Reverse: $\quad$ PM TRP II-COS PP}

Jupiter, nude, standing front, head to the left, holding thunderbolt in right hand over Gordian standing left and holding vertical sceptre in left hand;

Catalogue: RIC IV/3, no. 16;

Inv. no. 5522;
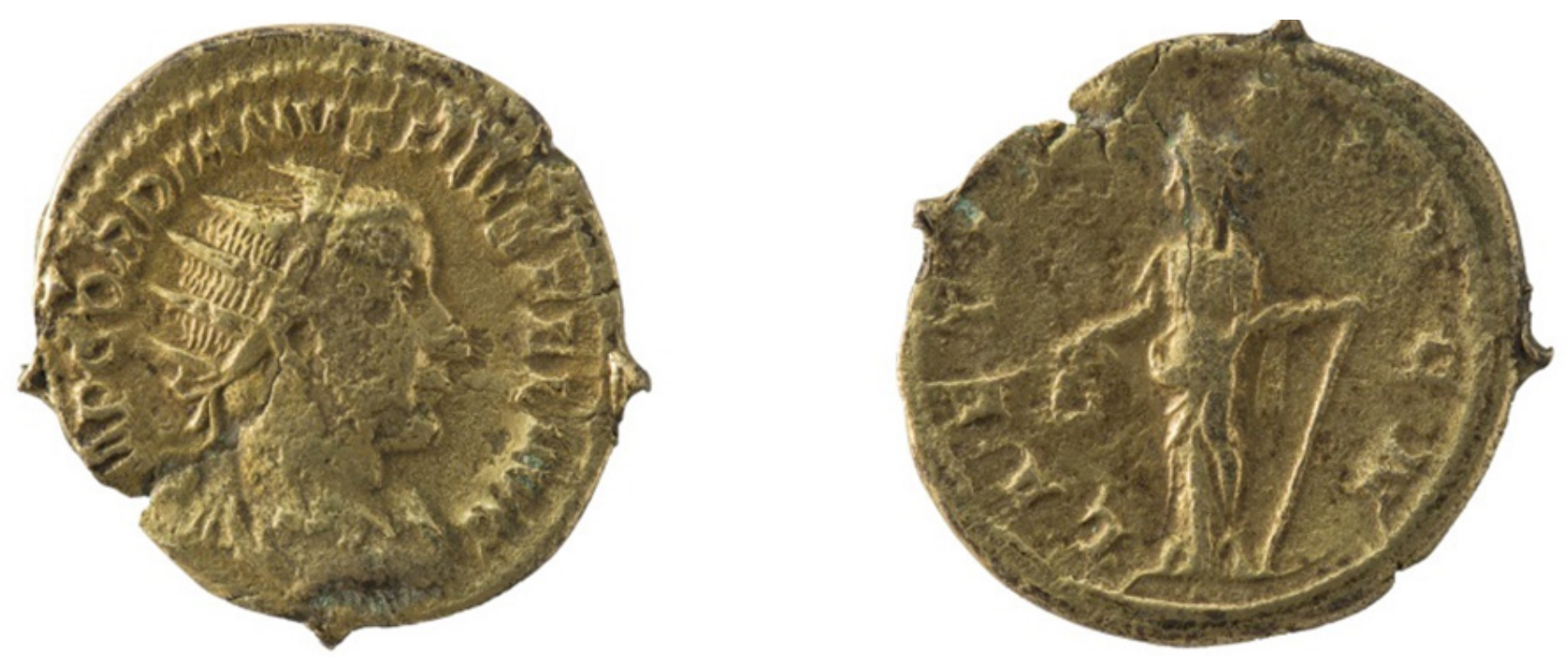

19.

Nominal: antoninianus;

Axis: 6. D: $22.9 \mathrm{~mm}$. W: $4.54 \mathrm{~g}$.

Mint: Rome;

Dating: 241-243;

Obverse: IMP GORDIANVS PIVS FEL AVG

Bust of Gordianus III, radiate, draped, cuirassed, to the right;

Reverse: LAETITIA AVG N

Laetitia standing to the left, holding wreath in right hand and anchor in left hand;

Catalogue: RIC IV/3, no. 86;

Inv. no. 5523; 

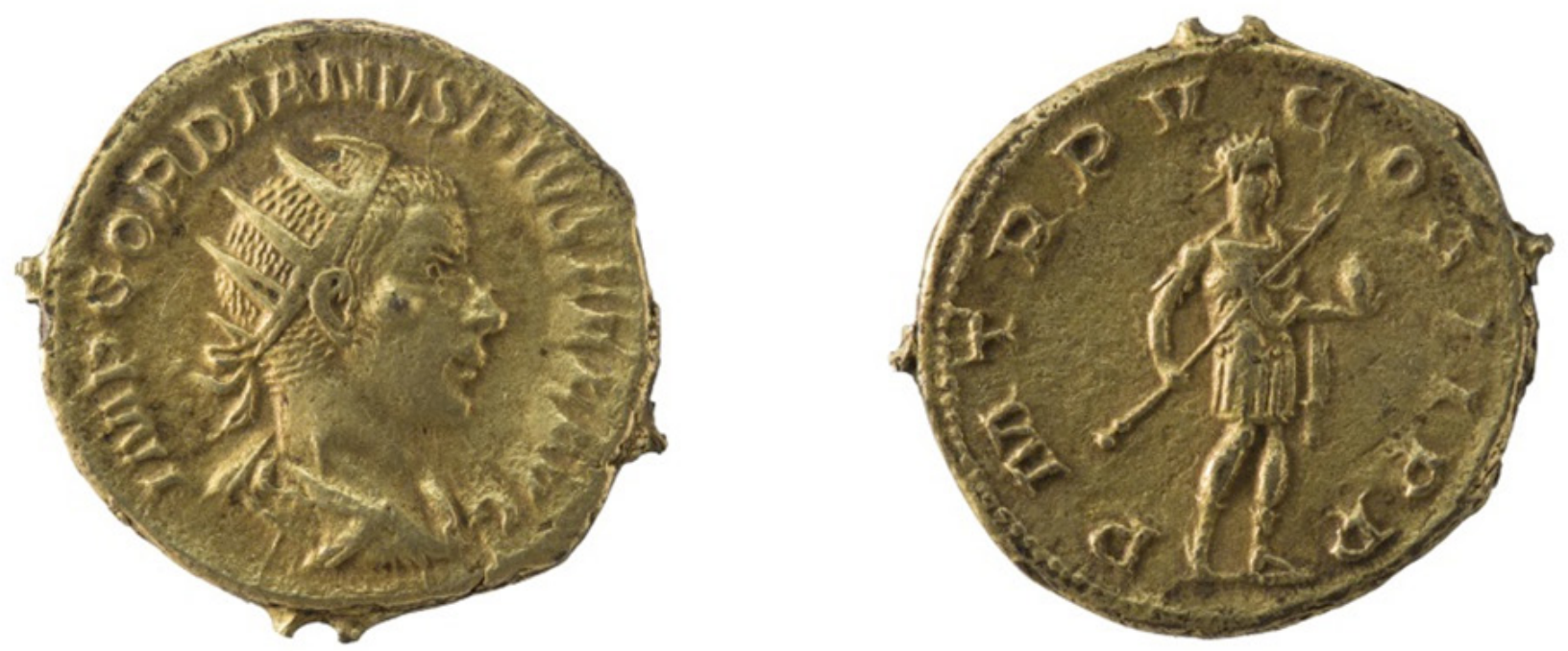

20.

Nominal: antoninianus;

Axis: 6. D: $20.5 \mathrm{~mm}$. W: $4.97 \mathrm{~g}$.

Mint: Rome;

Dating: 241-243;

Obverse: IMP GORDIANVS PIVS FEL AVG

Bust of Gordianus III, radiate, draped, cuirassed, to the right;

Reverse: PM TRP V COS PP

Gordian III, in military dress, standing to the right, holding a globe in left hand and transverse spear in right hand;

Catalogue: RIC IV/3, no. 93;

Inv. no. 5521;
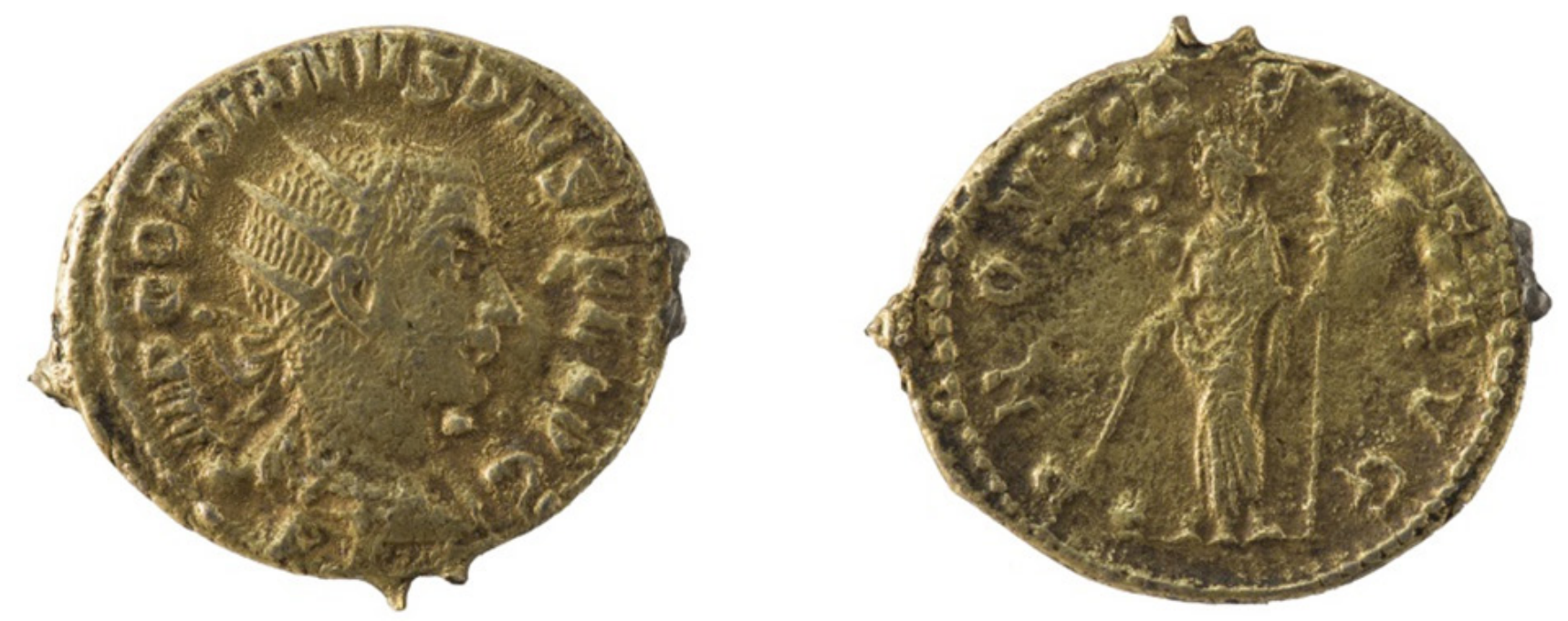

21.

Nominal: antoninianus;

Axis: 6. D: $21.6 \mathrm{~mm}$. W: $4.24 \mathrm{~g}$.

Mint: $\quad$ Rome;

Dating: 243-244;

Obverse: IMP GORDIANVS PIVS FEL AVG

Bust of Gordianus III, radiate, draped, cuirassed, to the right;

Reverse: PROVIDE-NT AVG

Providentia standing to the left, holding wand in right hand over globe and sceptre in left;

Catalogue: RIC IV/3, no. 149;

Inv. no. 5524; 


\section{PHILIPPVS I}
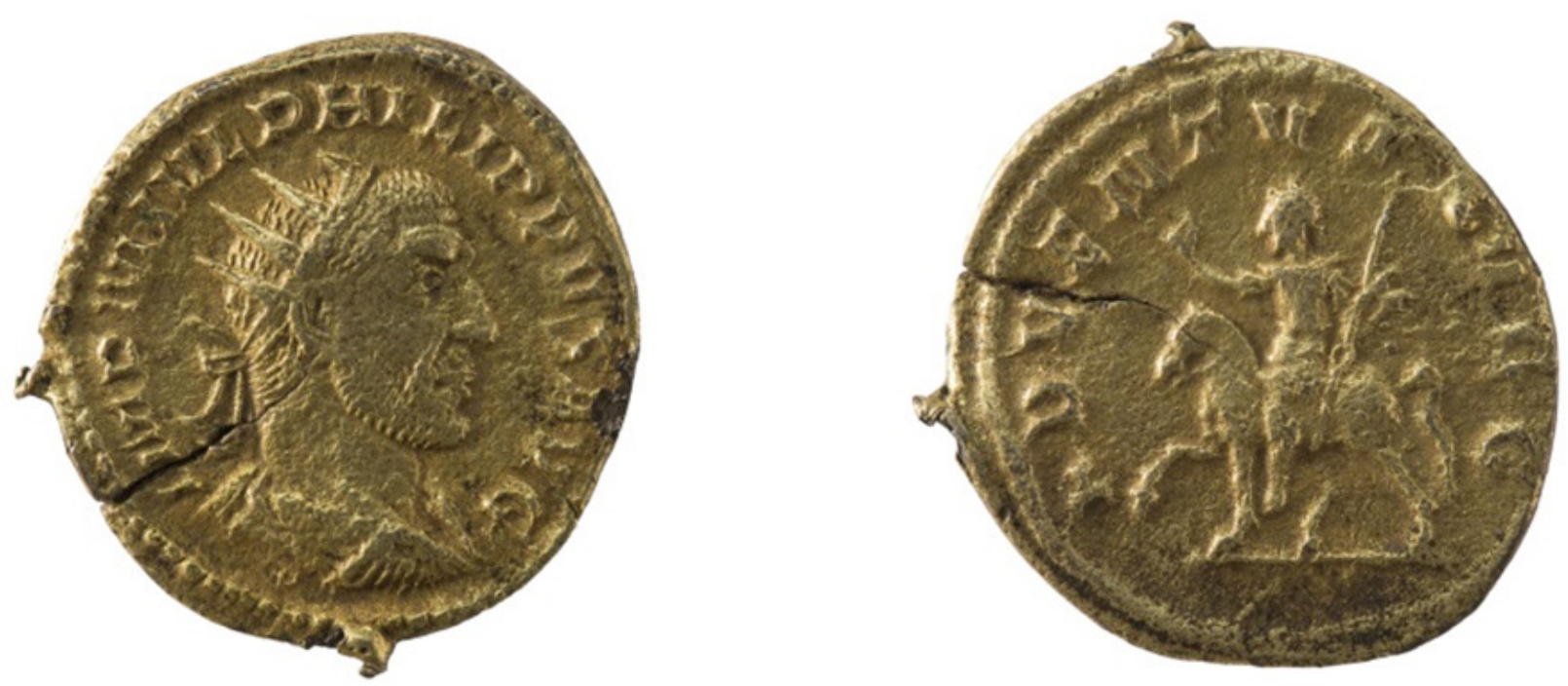

22.

Nominal: antoninianus;

Axis: 8. D: $22.5 \mathrm{~mm} . \quad W: 3.47 \mathrm{~g}$.

Mint: $\quad$ Rome;

Dating: 244-247;

Obverse: IMP M IVL PHILIPPVS AVG

Bust of Philip I, radiate, draped, cuirassed, to the right;

Reverse: ADVENTVS AVGG

Philip, on horse pacing to the left, raising right hand and holding spear in left hand;

Catalogue: RIC IV/3, no. 26b;

Inv. no. 5535;
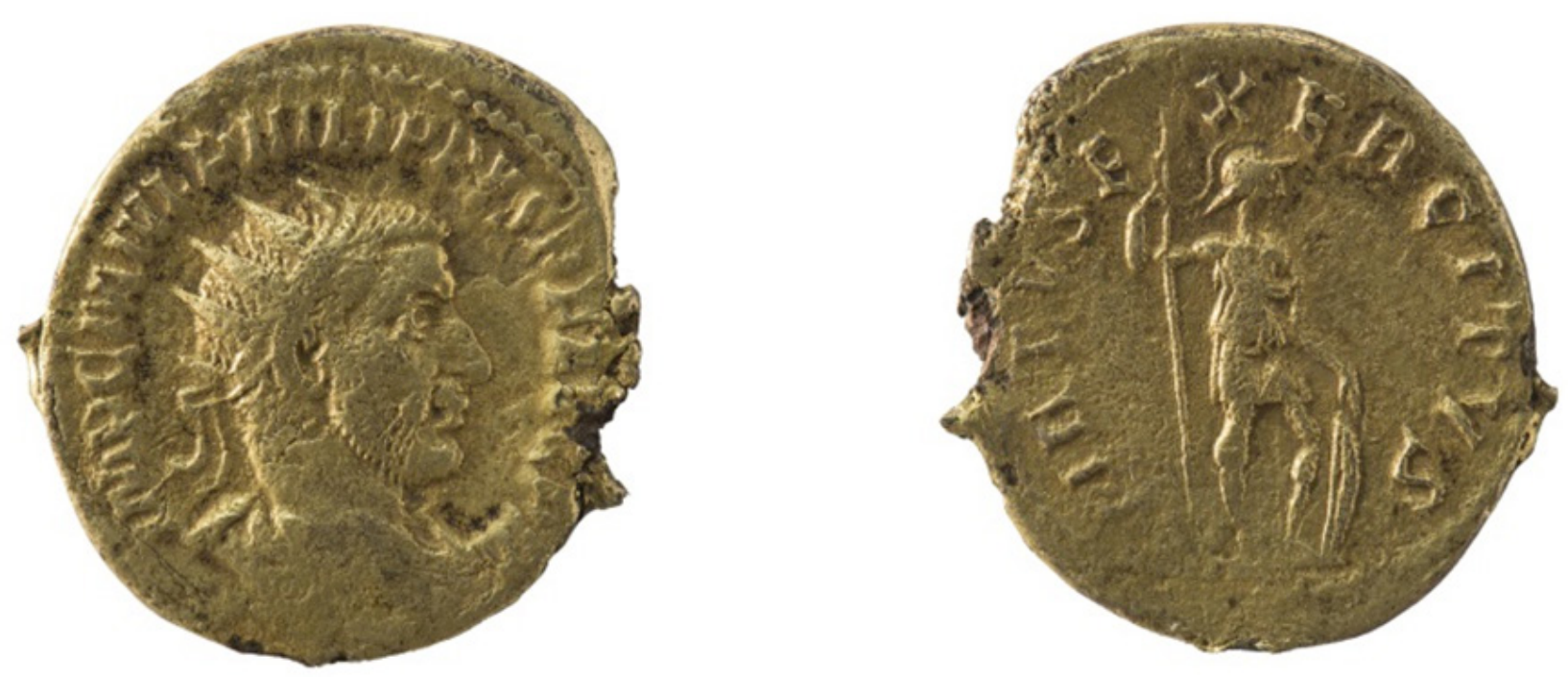

23.

Nominal: antoninianus;

Axis: $12 . \quad$ D: $23 \mathrm{~mm}$. W: $4.47 \mathrm{~g}$.

Mint: Antiohia;

Dating: 247-249;

Obverse: IMP C M IVL PHILIPPVS P F AVG P M

Bust of Philipus I, radiate, draped, cuirassed, to the right;

Reverse: [v]IRTVS E-XERCITVS

Virtus with helmeted, in military dress, standing to the right, holding spear in right hand and resting left hand on shield;

Catalogue: RIC IV/3, no. 71;

Inv. no. 5536; 
Finally, even if, due to the missing information about the context of discovery or the purchasing process, the description of the composition of this possible fragment of the hoard seems impossible, based on data gathered we can issue some conclusions. After analyzing these parts of hoard we can admit that these coins come from a much larger treasury which were found in a particular context (unknown to us) and shared between their discoverers or alienated to others immediately after they were unearthed. These 23 coins came from a person who gilded them in order to garnish their appearance and who wore them as a necklace and then they were bought by professor Alexandru Borza (see plates 1-3).

Another reason to consider that this monetary batch is part of a hoard is the presence of a large number of coins issued by the same kings (ex. Severus Alexander 6 denarii or Gordian III 4 antoniniani, see graph 2).

Among these coins some pieces that contain errors or defects were observed, such as non-uniform embossment, most likely due to failure of its sliding punch at the time of minting (catalogue nos. 1, 4, 7, 11, 12, 19, 20) (see plates). However, after a close examination of these pieces it was found that some coins were plated, this being noticed where they have fractures / cracks (catalogue nos. 9, 14, 16, 18, 23). It is possible that this batch of coins, the number of pieces that are represented by a silver foil (in this case, gold) to be bigger. Their presence in hoards is a common phenomenon, due to monetary policy allowed by the Roman Empire, especially during the reign of Septimius Severus; ${ }^{4}$

If we cannot admit that the first coin found in this thesaurus is from Septimius Severus, we can assume that the latter is issued by Philip I and, if we accept this version, then the reason for the concealment of this hoard and the impossibility of its recovering can be considered, from a military point of view, the invasion from the first half of the year $248 .^{5}$ This happened at the end of Philip reign and it was initiated by the Gothic people led by Argaithus and Gunthericus and their allies the Carps, the Taifals, the Peucini and the Vandals. ${ }^{6}$

Thus, we can say that this money fragment falls into the second group of completed hoard of coin from Philip and hidden, perhaps during the reign of Trajan Decius. ${ }^{7}$

We could say that in this horizon can be integrated among other hoards of the same type in Dacia, preciselely in Slăveni $I^{8}$ (Olt County), 1967, Slăveni II ${ }^{9}$ (Olt County), 1974, Tunarii $\operatorname{Vechi}^{10}$ (Dolj County), 1964. At the same time, other hoards such as Galicea Marealso ${ }^{11}$ (Dolj County), 1961, Moţăţei ${ }^{12}$ (Dolj County), Cîineni-Călineşti ${ }^{13}$ (Vâlcea County), Brădiceni ${ }^{14}$ (Gorj County), 1886, might be considered in the same group of hoards (at the end of Philip I reign), but we do

\footnotetext{
GĂZDAC/NEAGOE 2018, 11.

5 PETAC 1998, .33.

6 HUSAR 2002, 422

PURECE 2008, 102

GĂZDAC 2010, 18-19.

GĂZDAC 2010, 19.

10 GĂZDAC 2010, 18.

1 GĂZDAC 2010, 16.

2 GĂZDAC 2010, 20.

3 GĂZDAC 2010, 20.

14 GĂZDAC 2010, 21.
}

not know which was the reason of their burial ${ }^{15}$ (see map).

\section{ACKNOWLEDGEMENTS}

This work was supported by grants of Ministry of Research and Innovation, CNCS - UEFISCDI, projects number PN-III-P4-ID-PCE-2016-0021 within PNCDI III.

\section{REFERENCES}

RIC IV.1

\section{Catalogues}

Mattingly, H./Sydenham, E.: The Imperial Coinage, vol.IV.1

Pertinax to Geta (London 1936: Spink\&Son). RIC IV.2

Mattingly, H./Sydenham, E./Sutherland, C.H.V.: The Imperial Coinage, vol.IV.2 Macrinus to Pupienus (London 1938: Spink\&Son).

\section{RIC IV.3}

Mattingly, H./Sydenham, E./Sutherland, C.H.V.: The Imperial Coinage, vol.IV.3 Gordian III to Uranius Antoninus (London 1968: Spink\&Son).

\section{Works}

BLĂJAN 1985

Blăjan, M.: Circulaţia monetară în judeţul Alba,argument al continuităţii populaţiei romanice în Dacia posromană (270-sec VII e.n.). Apulum XXII, 93-110.

\section{BORZA 1963}

Borza, A.: Amintirile unui botanist din Alba Iulia. Note autobiografice.

\section{GĂZDAC 2010}

Găzdac, C.: Monetary circulation in Dacia and the provinces from the Middle and Lower Danube from Trajan to Constantine I (AD 106-337) [Coins from Roman Sites and Collections of Roman Coins from Romania 7]. (Cluj-Napoca: Mega Publishing House).

GĂZDAC/NEAGOE 2018

Găzdac, C./Neagoe, M.: Sărac sau bogat în timp de pericol? Tezaurul imperial roman de la Gruia (jud. Mehedinţi) [Coins from Roman Sites and Collections of Roman Coins from Romania 12]. (Cluj-Napoca: Mega Publishing House).

HUSAR 2002

Husar, A.: Din istoria Daciei romane. Structuri de civilizaţie. PETAC 1998 (Cluj-Napoca: Presa Universitară Clujeană).

Petac, E.: Consideraţii cu privire la data finală a tezaurelor monetare îngropate la mijlocul sec. III p. Chr. în Dacia romană de la sud de Carpaţi. Studii şi cercetări de numismatică XII, 27-40.

PURECE 2008

Purece, S.I.: Orizonturile de tezaure din zona de sud a Provinciei Dacia - Discuţii şi ipoteze. In: Monedă şi comerţ in sud-estul Europei II, Biblioteca Brukenthal XXII, 91-113.

WINKLER 1965

Winkler, I.: Circulaţia monetară la Apulum. Acta Musei Napocensis II, 215-251. 


\section{PROPORTION OF DENOMINATIONS}

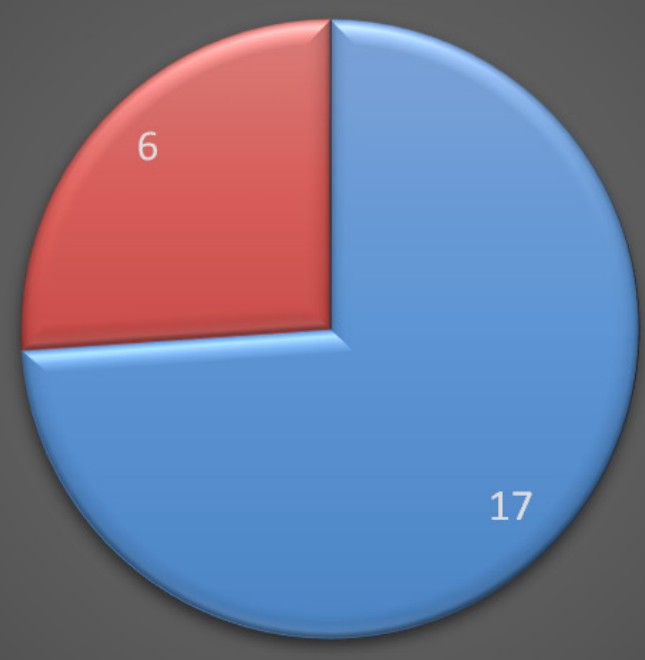

$\square$ DENARI $\square$ ANTONINIANI

\section{COINS BY ISSUERS}

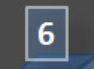

$\square$ DENARI

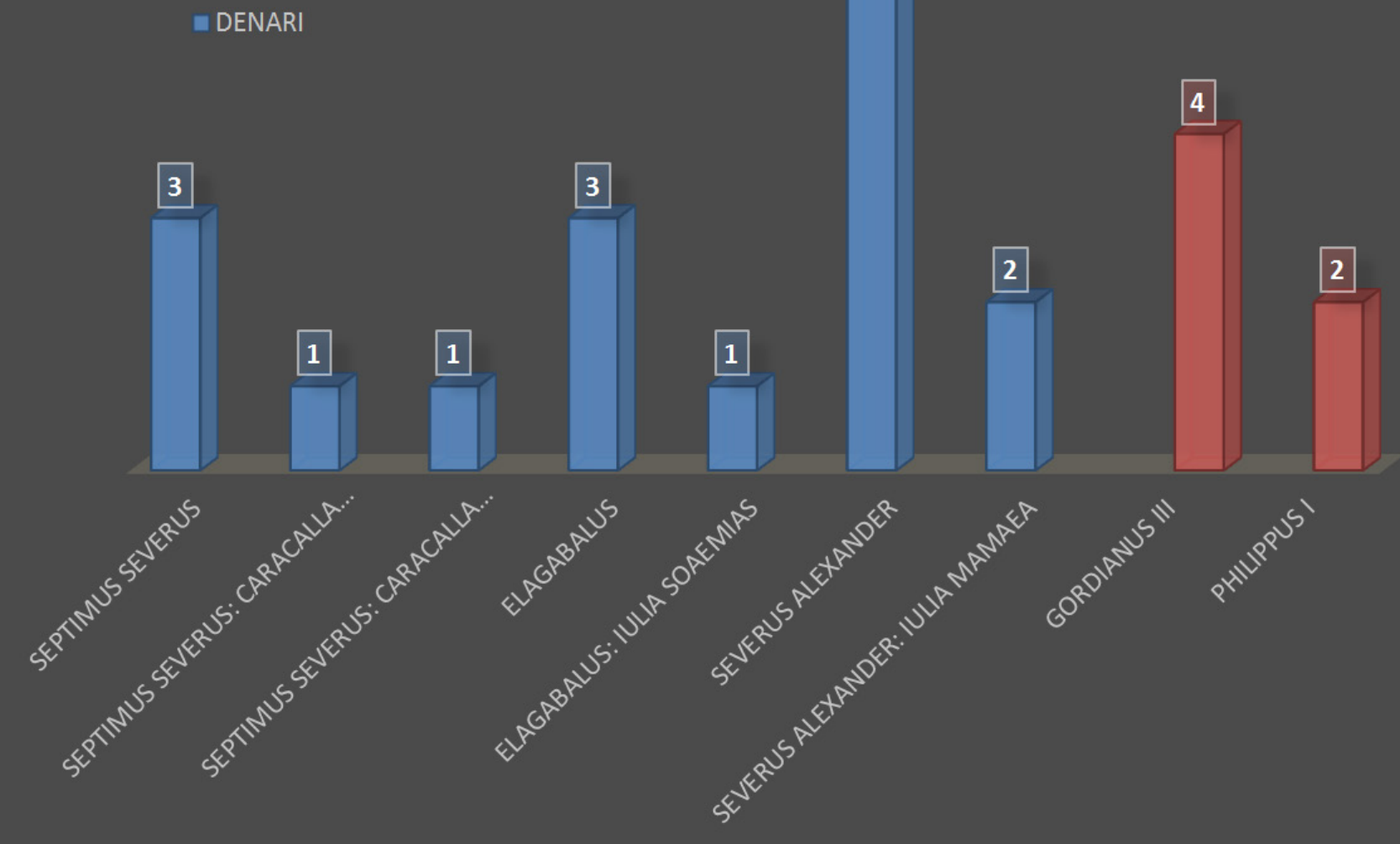




\section{Studies

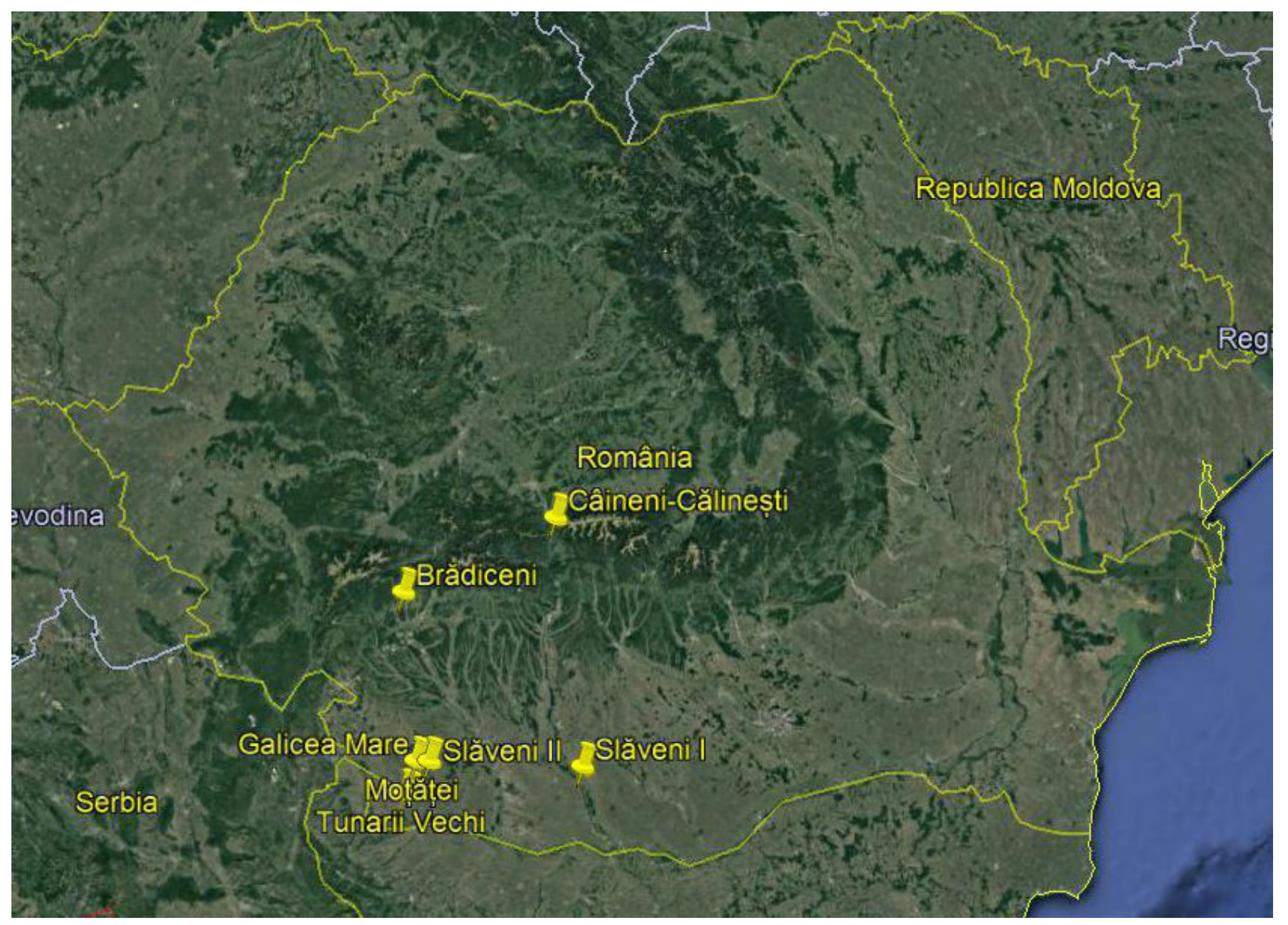

Map of hoards from the former territory of Dacia (broadly, nowadays, Romania) ending with coins from Philip I. 

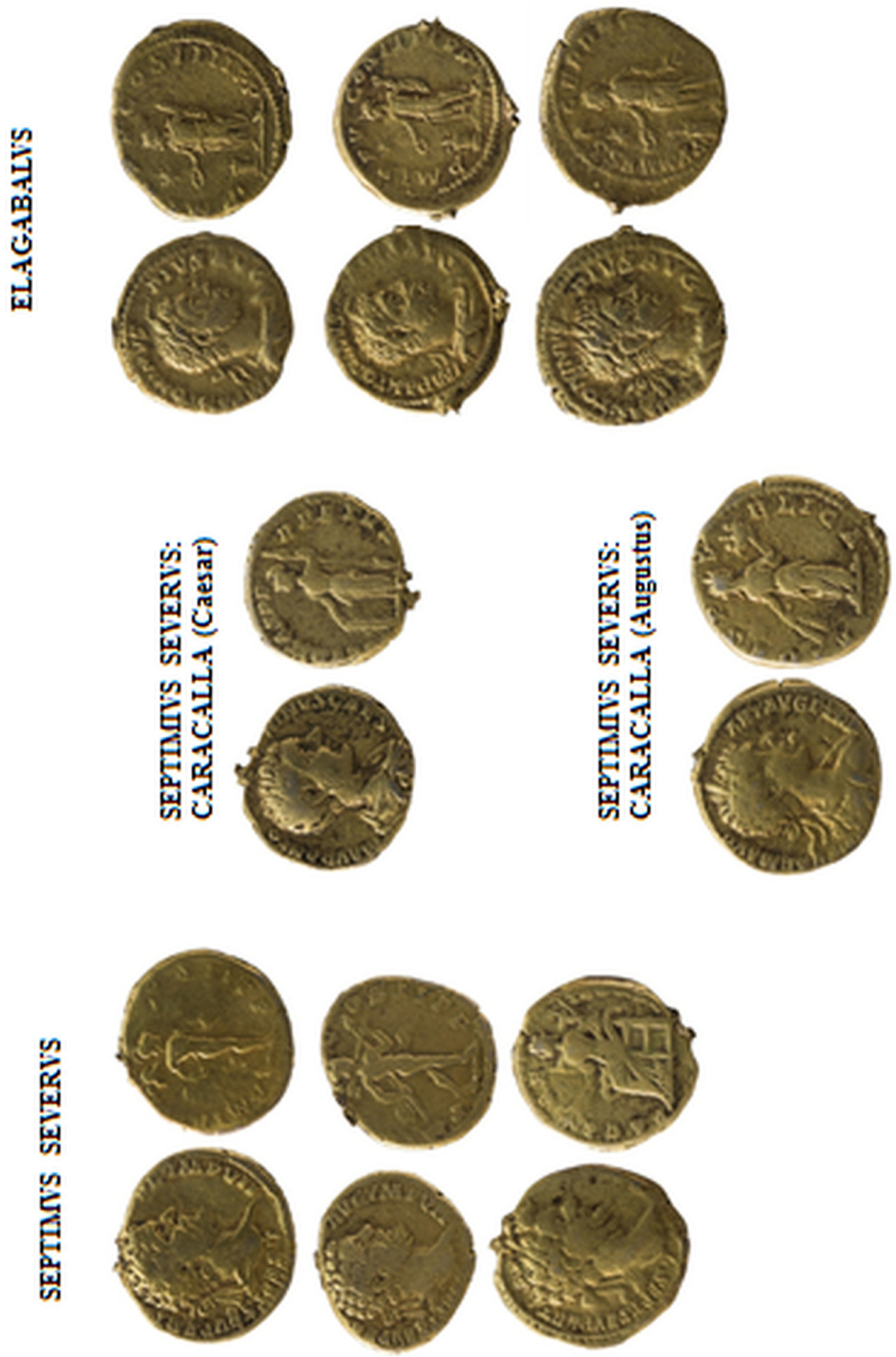


\section{ELAGA B ALVS: Iulia Soaemias}
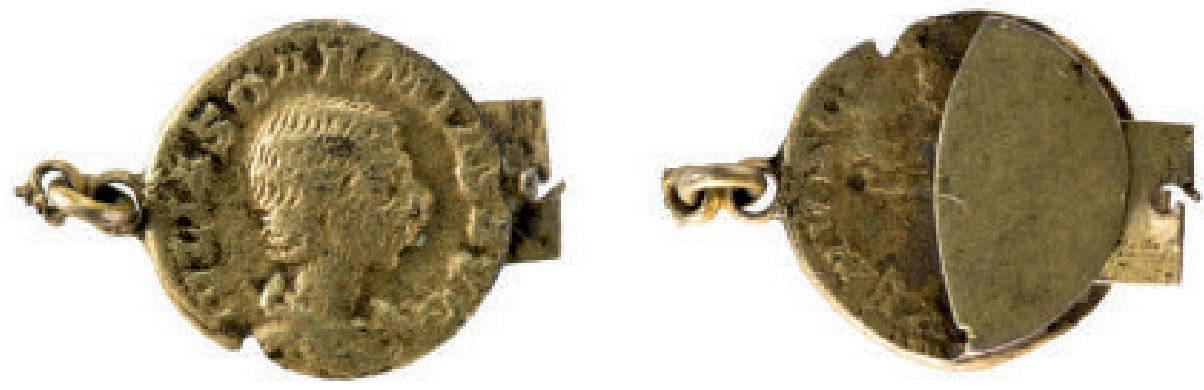

SEVERUS ALEXANDER
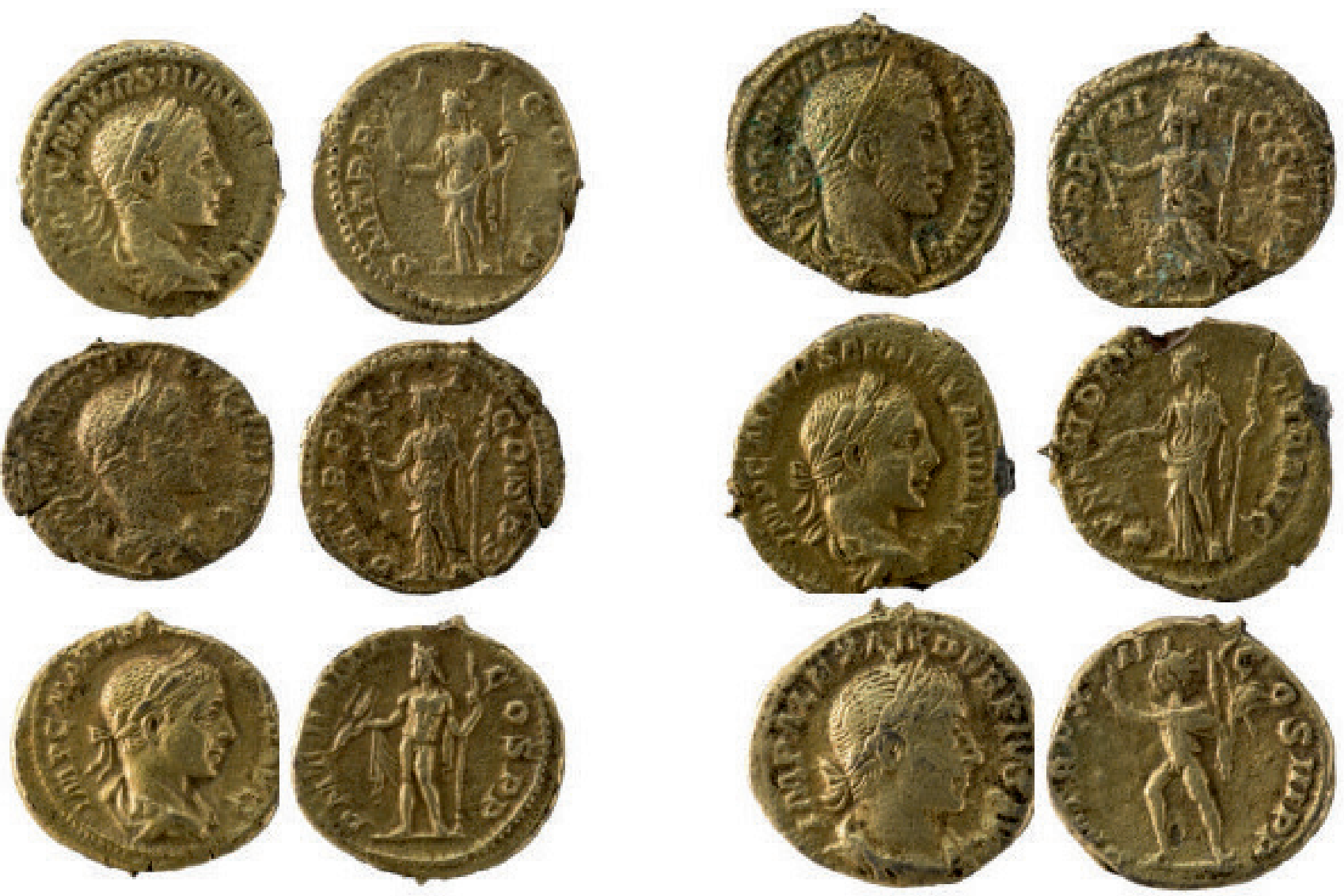

Pl. 2. 

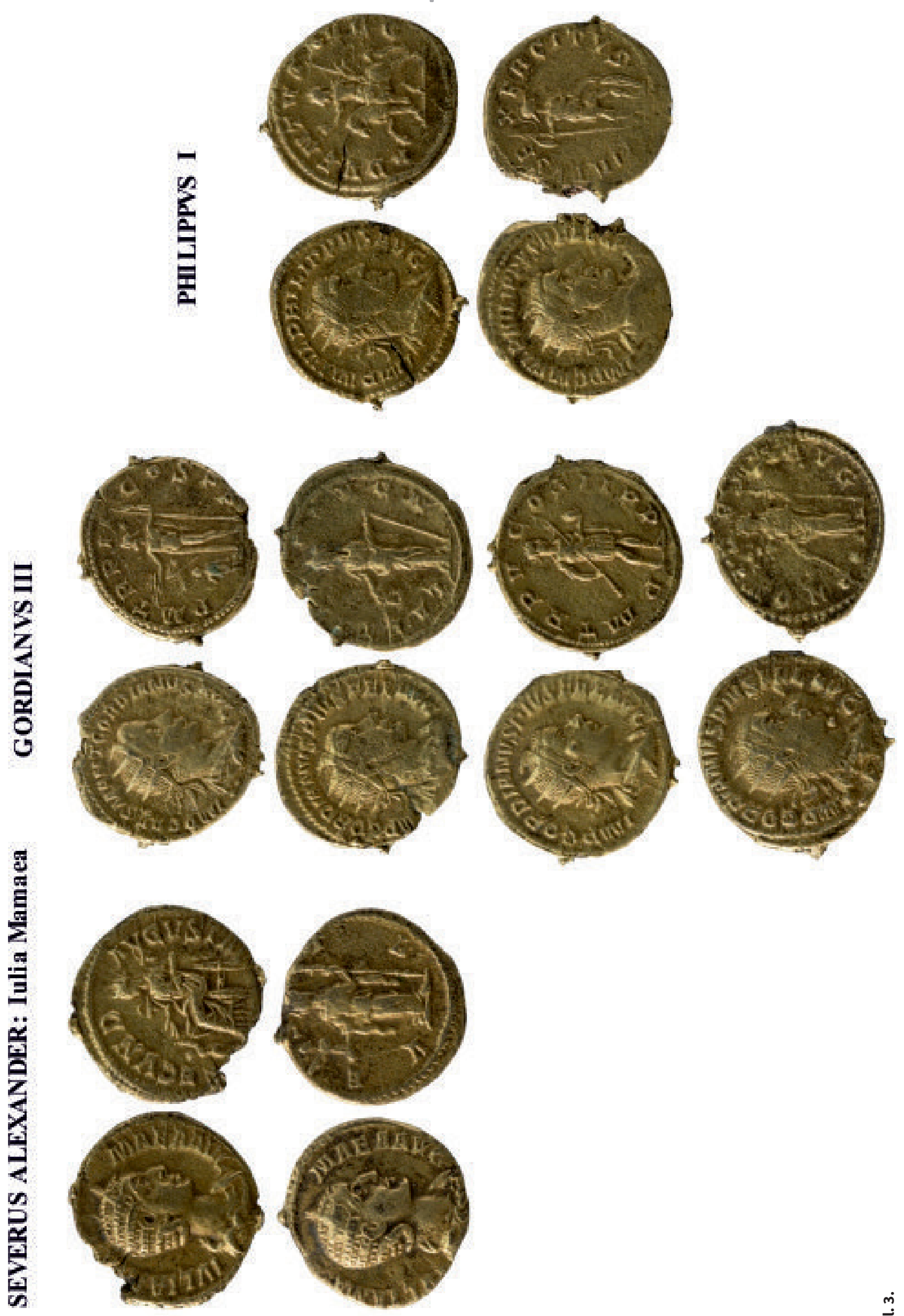